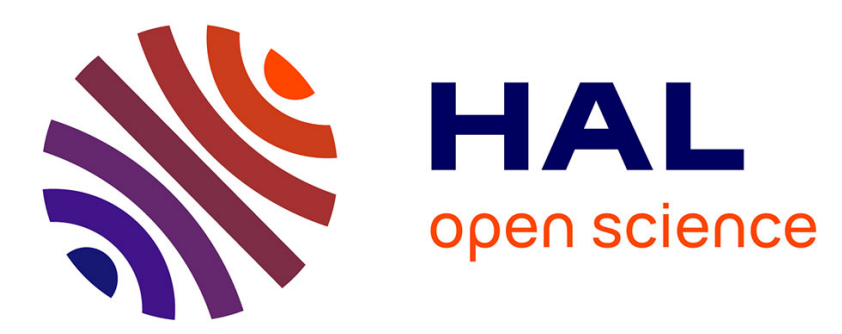

\title{
Impact of the support on the catalytic activity of Ag nanoparticles for soot combustion
}

Adrien Serve, A. Boreave, Bruno Cartoixa, Karine Pajot, Philippe Vernoux

\section{To cite this version:}

Adrien Serve, A. Boreave, Bruno Cartoixa, Karine Pajot, Philippe Vernoux. Impact of the support on the catalytic activity of Ag nanoparticles for soot combustion. Catalysis Today, 2021, 363, pp.93-104. 10.1016/j.cattod.2019.11.010 . hal-03161739

\section{HAL Id: hal-03161739 \\ https://hal.science/hal-03161739}

Submitted on 12 Nov 2021

HAL is a multi-disciplinary open access archive for the deposit and dissemination of scientific research documents, whether they are published or not. The documents may come from teaching and research institutions in France or abroad, or from public or private research centers.
L'archive ouverte pluridisciplinaire HAL, est destinée au dépôt et à la diffusion de documents scientifiques de niveau recherche, publiés ou non, émanant des établissements d'enseignement et de recherche français ou étrangers, des laboratoires publics ou privés.

\section{(ㄷ)(1) $\$$}

Distributed under a Creative Commons Attribution - NonCommerciall 4.0 International 


\title{
Impact of the support on the catalytic activity of $\mathrm{Ag}$ nanoparticles for soot combustion
}

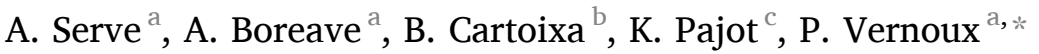

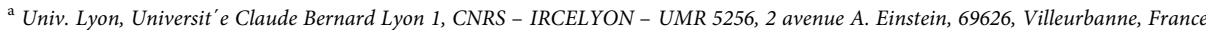 \\ ${ }^{\mathrm{b}}$ CTI, C'eramiques Techniques Industrielles, 382 Avenue du Moulinas, 30340, Salindres, France \\ ${ }^{\mathrm{c}}$ Groupe PSA, Centre technique de V'elizy, Route de Gisy, 78943, V'elizy-Villacoublay, France
}

\begin{abstract}
This study investigates the catalytic activity for soot combustion of Ag nanoparticles dispersed on various supports showing different redox properties. Temperature programmed soot oxidation and isotopic exchange experiments were performed to assess the impact of the soot/catalyst contact, the oxygen partial pressure and the ageing toward activity. Three different contact modes have been used to clearly highlight the catalytic performances: loose, tight and supertight. Whatever the support, in both loose and tight contact modes, the catalytic performances are linked with the Ag surface concentration which was found to be high on zirconia-based catalysts and low on ceria-zirconia. The ignition of the soot combustion process occurs on $\mathrm{Ag}$ nanoparticles except for catalysts supported on Yttria-Stabilized Zirconia (YSZ), a pure oxygen ionic conductor, where Ag nanoparticles only promote the run-away of the reaction at higher temperatures. Catalysts based on $\mathrm{SiO}_{2}, \mathrm{ZrO}_{2}$ and YSZ exhibit a remarkable hydrothermal stability as performances in tight contact mode are fairly similar after the hydrothermal ageing.
\end{abstract}

\section{Introduction}

Particulate Matter (PM) emission abatement for passenger Diesel vehicles has become more and more stringent over the past years. In 2009, newly implemented Euro 5 standards lead to Diesel Particle Filter (DPF) becoming widespread to reduce PM emissions. DPF proved to be an efficient way to trap soot particles in the exhaust, the main drawback being the necessity to regenerate the filter regularly as soot collection slowly obstructs the filter, increasing the pressure drop. As temperature in the DPF is too low for oxidizing soot, fuel post-injections are commonly used to regenerate DPF regeneration. Post-injected fuel is oxidized in the Diesel Oxidation Catalyst (DOC), enhancing the temperature up to $600{ }^{\circ} \mathrm{C}$ in the DPF due to the exothermicity of the oxidation reactions, thus allowing soot oxidation. This strategy causes a fuel overconsumption which is detrimental to the overall $\mathrm{CO}_{2}$ emission assessment of Diesel vehicles.

The aim of this study it to develop an active catalyst for the DPF regeneration at low temperature using only oxygen as an oxidant. Ceria oxides are good candidates due to their redox properties: surface oxygen vacancies can generate active oxygen species such as $\mathrm{O}_{2}^{-}$and $\mathrm{O}^{-}[1-3]$. Perovskites have been also reported to be efficient through the involvement of weakly chemisorbed surface oxygen species as well as bulk oxygen species, who can migrate toward the oxidation site thanks to the ionic conductivity [4-7]. We have also shown that Yttria-Stabilized Zirconia (YSZ), a well-known pure oxygen ionic conductor, can oxidize soot [8-10] with lattice oxygen active species with a concomitant gaseous oxygen replenishment into the lattice. Soot oxidation observed by E-TEM (Environmental Transmission Electronic Microscope) displayed that the reaction occurred at the soot/YSZ interface [8]. Using isotopic experiments, we have proposed a fuel-cell type electrochemical mechanism to explain the ignition of the soot oxidation on YSZ. The soot could be electrochemically oxidized with ionic $\mathrm{O}^{2-}$ species at the soot/YSZ interface whereas YSZ is replenished via gas-phase oxygen electrochemical reduction at the triple phase boundary (tpb) gas/soot/YSZ. As in fuel cells, the electromotive force of this process is the gradient of oxygen concentration between the tpb and the soot/YSZ interface. This process is limited by the kinetic of the incorporation of gaseous oxygen into YSZ. Recently [11], we demonstrated that the presence of silver nanoparticles (Ag NPs) over YSZ enhanced soot oxidation performances in both loose and tight contact modes. Ag NPs were shown to boost soot oxidation activity by promoting the dissociative adsorption and lattice integration of gaseous

\footnotetext{
* Corresponding author.

E-mail address: philippe.vernoux@ircelyon.univ-lyon1.fr (P. Vernoux).
} 
oxygen into the YSZ support. Ag/YSZ catalysts have shown promising catalytic performances for low $\mathrm{Ag}$ loadings in the range 1-2 wt.\%.

This paper describes catalytic activity for soot combustion of Ag NPs dispersed on various supports showing different redox properties: $\mathrm{SiO}_{2}$ as a non-redox oxide with a large specific surface area, ceria-zirconia as a reference redox material [12,13], YSZ as a pure oxygen ionic conductor and non-doped $\mathrm{ZrO}_{2}$ for comparison. This study mainly focused on the hydrothermal stability of the $\mathrm{Ag}$ supported catalysts. In addition, two kinds of YSZ powders were used with different surface properties and grain sizes. Various characterization techniques (XPS, TEM, UV-vis, $\mathrm{H}_{2}$-TPR) were carried out to investigate the Ag NPs oxidation state, shape and dispersion. Temperature programmed soot oxidation were performed to assess the impact of the soot/catalyst contact, the oxygen partial pressure and the ageing toward activity. Three different contact modes have been used to clearly highlight the catalytic performances of the catalysts: loose, tight and supertight. The latter has been obtained from propene cracking which can produce a nanometric carbon film onto the catalyst surface. Finally, Temperature-Programmed Isotopic Exchange experiments were performed to get further insight into the catalytic mechanism.

\section{Experimental}

\subsection{Catalysts preparation and characterizations}

Supports used were commercial YSZ ( $8 \%$ mol yttria) and non-doped zirconia $\left(\mathrm{ZrO}_{2}\right)$ purchased from Tosoh company, YSZb (also containing $8 \%$ mol yttria) furnished by Céramiques Techniques Industrielles, $\mathrm{SiO}_{2}$ from Sigma-Aldrich and ceria-zirconia $\left(\mathrm{Ce}_{0.7} \mathrm{Zr}_{0.3} \mathrm{O}_{2}\right)$ supplied by Solvay company. These materials were impregnated with a silver nitrate aqueous solution obtained by dissolution of $\mathrm{AgNO}_{3}$ (Sigma Aldrich, purity 99\%) to achieve $1,3 \mathrm{wt} \% \mathrm{Ag}$ loading. Indeed, according to reference [11], the optimal Ag loading to reach the highest catalytic performance was in the range $1-2 \mathrm{wt} \%$. Samples were dried overnight at $100{ }^{\circ} \mathrm{C}$ and finally annealed at $700{ }^{\circ} \mathrm{C}$ for $4 \mathrm{~h}$ in flowing air [11]. Table 1 summarizes the list of the as-prepared Ag supported catalysts (denoted as calcined) and their nomenclature. Hydrothermal ageing was carried out at $900{ }^{\circ} \mathrm{C}$ for $10 \mathrm{~h}$ in flowing air containing 10 vol. $\% \mathrm{H}_{2} \mathrm{O}$ (denominated aged in Table 1). Silver loading was determined by ICP-OES using a Horiba Jobin Yvon Activa spectrometer. XRD diffractograms were recorded with a Bruker D8 Advance A25 diffractometer using $\mathrm{Cu} \mathrm{K} \alpha$ radiation. Specific Surface Areas (SSA) were measured from $\mathrm{N}_{2}$ adsorption at $-196^{\circ} \mathrm{C}$ (BET method), using a Tristar Surface Area and Porosity Measurement apparatus from Micromeritics. The BJH method was used to determine the pore size distribution. Silver and support average crystallites size were calculated using the Scherrer equation when corresponding peaks intensities were high enough to obtain accurate data. Samples d50 (grain diameter at half distribution) was measured using a Laser diffraction spectroscopy.

XPS spectra were recorded for each catalysts on an AXIS Ultra DLD from Kratos Analytical using a monochromatized Al X-ray source $(\mathrm{hv}=1486,6 \mathrm{eV})$. Sample were pretreated at $200^{\circ} \mathrm{C}$ in $\mathrm{He}$ before

Table 1

Support grain size, silver loadings and average silver particle crystallite size obtained by the Scherrer equation after calcination at $700^{\circ} \mathrm{C}$ and hydrothermal ageing.

\begin{tabular}{|c|c|c|c|c|c|c|}
\hline \multirow[t]{2}{*}{ Catalysts } & \multirow[t]{2}{*}{$\mathrm{d} 50(\mu \mathrm{m})$} & \multicolumn{2}{|c|}{ Ag loading (\%wt) } & \multirow[t]{2}{*}{ Ag loss (\%) } & \multicolumn{2}{|c|}{$\begin{array}{l}\text { Average Ag NPs } \\
\text { cristallite size (nm) }\end{array}$} \\
\hline & & Calcined & Aged & & Calcined & Aged \\
\hline 1Ag/YSZ & 68 & 1.1 & 0.8 & 27 & $31 \pm 6$ & $48 \pm 4$ \\
\hline $1 \mathrm{Ag} / \mathrm{YSZb}$ & 0.3 & 1.2 & 1.1 & 8 & $36 \pm 6$ & $52 \pm 6$ \\
\hline $1 \mathrm{Ag} / \mathrm{ZrO}_{2}$ & 68 & 1.1 & 0.9 & 18 & - & $61 \pm 6$ \\
\hline $1 \mathrm{Ag} / \mathrm{SiO}_{2}$ & 0.3 & 1.3 & 1.2 & 7 & $16 \pm 2$ & $36 \pm 3$ \\
\hline $1 \mathrm{Ag} / \mathrm{CZ}$ & 6 & 1 & 0.6 & 40 & - & - \\
\hline
\end{tabular}

measurements to clean the surface, scanning energy was $40 \mathrm{eV}$ for every region. Peaks were referenced using $\mathrm{C} 1 \mathrm{~S}$ peak of carbon $(\mathrm{BE}=284.6 \mathrm{eV})$.

Calcined and aged samples were observed by TEM using a JEOL 2010 microscope. Acceleration voltage was $200 \mathrm{kV}$ with a $0.2 \mathrm{~nm}$ resolution. Samples were previously dispersed in ethanol using an ultrasound bath and then deposited on a copper mesh. Ag NPs diameter distribution was estimated over an average of 20 micrographs per catalyst by measuring at least $150 \mathrm{Ag}$ NPs.

UV-Vis analysis were performed on calcined samples at room temperature in ambient air using a Lambda 950 UV-vis spectrophotometer (Perkin Elmer) equipped with an integrating sphere detector. Reflectance was measured and converted to absorbance using a Kubelka-Munk function. Blanks were performed prior to each experiments by using a Spectralon sample.

Temperature programmed reduction experiments were carried out over all calcined catalysts. $200 \mathrm{mg}$ of catalyst were deposited in a U shaped quartz reactor. A reactive mixture of $1 \% \mathrm{H}_{2} / \mathrm{He}$ was introduced at $6 \mathrm{~L} . \mathrm{h}^{-1}$ and the reactor was heated with a heating ramp of $10{ }^{\circ} \mathrm{C} / \mathrm{min}$ rate up to $450^{\circ} \mathrm{C}$. $\mathrm{H}_{2}(\mathrm{~m} / \mathrm{z}=2)$ signal was recorded using an Inficon quadrupole mass spectrometer. Signal calibration was performed prior to and after every experiments to assess the potential signal deviation of the MS over time.

\subsection{Catalytic performances measurements}

Soot oxidation activity was measured by TPO (Temperature Programmed Oxidation) of a mixture of a model soot (Printex $U$ ) and the catalyst under $5 \% \mathrm{O}_{2} / \mathrm{He}$ with an overall flow of $100 \mathrm{~mL} / \mathrm{min}$. Temperature ramp was $10^{\circ} \mathrm{C} / \mathrm{min}$ from room temperature up to $750{ }^{\circ} \mathrm{C}$. Two contact modes between model soot particles and catalyst grains were investigated. The "tight" contact mode was obtained by grinding the catalyst and the soot together in a ball-mortar containing two zirconia balls of $5 \mathrm{~mm}$ diameter at $15 \mathrm{~Hz}$ for $2 \mathrm{~min}$. "Loose" contact mixture was obtained by only mixing the two elements with a spatula for $5 \mathrm{~min}$. "Tight" contact mode leads to improved contact between soot and catalyst and is generally used to assess the intrinsic activity of the catalyst toward soot oxidation. The "Loose contact" mode is considered to be more representative of the poor contact quality obtained between a catalyst wash-coat and soot particles trapped in a catalyzed-DPF [14, 15]. TPO experiments reproducibility was checked by conducting experiments twice. Soot to catalyst mass ratio was $1 / 4,25 \mathrm{mg}$ of the soot/catalyst mixture was introduced in a U-tube quartz reactor. Outlet gases ( $\mathrm{CO}$ and $\mathrm{CO}_{2}$ ) were analyzed by a micro-chromatograph from SRA. In addition, the $\mathrm{CO}_{2}$ concentration was on-line measured with a Horiba IR analyzer. Soot to gas conversion was obtained by integration of the molar production rate of $\mathrm{CO}$ and $\mathrm{CO}_{2}$ with respect to time during soot oxidation experiments, followed by normalization with respect to the total amount of soot initially present in the reactor. Soot to gas conversion allowed for determination of $\mathrm{T}_{10}$ and $\mathrm{T}_{50}$ values, corresponding respectively to temperatures at which $10 \%$ and $50 \%$ of the soot is converted to gas.

\subsection{Propene cracking}

To get further insight into the intrinsic activity of the catalyst to oxidize carbon, a nanometric carbon layer was in-situ deposited on the catalyst surface by propene cracking (1). $200 \mathrm{mg}$ of each sample was introduced in $\mathrm{U}$-shaped quartz reactor and reduced at $500^{\circ} \mathrm{C}$ under pure hydrogen during $30 \mathrm{~min}$ to limit the reaction between propene and adsorbed oxygen species. Then, samples were heated up to $600{ }^{\circ} \mathrm{C}$ under $\mathrm{He}$ and a mixture of propene in helium (8000 ppm) was introduced for $30 \mathrm{~min}$. Reactor was then flushed with $\mathrm{He}$ and cooled down rapidly to room temperature. TPO was then performed in $5 \% \mathrm{O}_{2} / \mathrm{He}$ at $10{ }^{\circ} \mathrm{C} / \mathrm{min}$ up to $600^{\circ} \mathrm{C}$. Deposited carbon quantity was estimated from $\mathrm{CO}$ and $\mathrm{CO}_{2}$ produced during the TPO. The production of hydrogen at $600^{\circ} \mathrm{C}$ as well as the concomitant consumption of propene were checked by using a 
mass spectrometer (HIDEN, HPR20). No oxidation products such as CO or $\mathrm{CO}_{2}$ were detected for all samples with the exception of $\mathrm{CZ}$ where considerable amounts of $\mathrm{CO}$ were produced during the first minutes. Small amounts of methane were also detected during the first minutes of propene cracking.

$\mathrm{C}_{3} \mathrm{H}_{6} \rightarrow 3 \mathrm{C}(\mathrm{s})+3 \mathrm{H}_{2}(\mathrm{~g})$

A second streak of tests was then carried out with a propene cracking time adjusted for each oxide support in order to obtain a deposition in the range 30-40 $\mu$ moles of carbon. Cracking time ranged from 10 to 30 min depending on the sample.

\subsection{Temperature-programmed Isotopic exchange (TPIE)}

TPIE experiments were performed over each calcined catalysts to investigate the impact of the support on the rate of oxygen exchange. A reactive mixture with labeled oxygen, $1 \%{ }^{18} \mathrm{O}_{2} / \mathrm{He}$, was obtained by dilution of pure marked $\mathrm{O}_{2}\left(97.1 \%{ }^{18} \mathrm{O}, 0.8 \%{ }^{17} \mathrm{O}, 2.1 \%{ }^{16} \mathrm{O}\right)$ obtained from EURISOTOP in He. A flow of $75 \mathrm{ml} / \mathrm{min}$ was introduced in a quartz reactor containing $200 \mathrm{mg}$ of catalyst. Heating rate was $5^{\circ} \mathrm{C} / \mathrm{min}$ from room temperature to $700^{\circ} \mathrm{C}$. A Hiden quadrupole mass spectrometer was used to analyze the outlet gases, signals $\mathrm{m} / \mathrm{z}$ followed were 32,34 and 36. Signal calibration was performed by using a $1 \%{ }^{16} \mathrm{O}_{2} / \mathrm{He}$ (99.99\% purity) calibration bottle provided by Linde. A blank experiment in presence of both $1 \%$ of ${ }^{16} \mathrm{O}_{2}$ and ${ }^{18} \mathrm{O}_{2}$ in the reactor was performed without any catalyst to check that gaseous homoexchange in the gas phase does not take place until $700{ }^{\circ} \mathrm{C}$.

Molar fractions of oxygen isotopomers were calculated by using (2):

$\mathrm{F}_{32}=\mathrm{C}_{32} /\left(\mathrm{C}_{32}+\mathrm{C}_{34}+\mathrm{C}_{36}\right)$

where $\mathrm{F}$ is an isotopomer molar fraction and $\mathrm{C}_{32}, \mathrm{C}_{34}$ and $\mathrm{C}_{36}$ are the respective concentrations of the three $\mathrm{O}_{2}$ isotopomers detected during the experiment. The ${ }^{18} \mathrm{O}_{2}$ consumption rate $\left(\mathrm{R}_{\text {consumption, } \mathrm{T}}\right)$ and the production rate $\left(\mathrm{R}_{\text {production, } \mathrm{T}}\right)$ of normal oxygen $\left({ }^{16} \mathrm{O}_{2}\right)$ at a given temperature $\mathrm{T}$ was calculated using (3) and (4) equations.

$\mathrm{R}_{\text {consumption, } \mathrm{T}}=\mathrm{F}^{*}\left(\mathrm{~F} 36_{\text {in }, \mathrm{T}}-\mathrm{F} 36_{\text {out }, \mathrm{T}}\right) / \mathrm{V}_{\mathrm{m}}$

$\mathrm{R}_{\text {production, } \mathrm{T}}=\mathrm{F}^{*}(\mathrm{~F} 32$ out, $\mathrm{T}) / \mathrm{V}_{\mathrm{m}}$

where $\mathrm{F}(\mathrm{L} / \mathrm{s})$ is the total flow rate, $\mathrm{F} 36_{\mathrm{in}, \mathrm{T}}$ is the oxygen fraction at the reactor's inlet, $\mathrm{F} 36$ out, $\mathrm{T}$ and $\mathrm{F} 32_{\text {out, } \mathrm{T}}$ are the ${ }^{18} \mathrm{O}_{2}$ and ${ }^{16} \mathrm{O}_{2}$ fractions measured at the reactor's outlet at temperature $\mathrm{T}$, and $\mathrm{V}_{\mathrm{m}}$ is the molar volume. Without production of ${ }^{16} \mathrm{O}^{18} \mathrm{O}$ in the gas phase, the surface oxygen exchange rate corresponds to the consumption rate of ${ }^{18} \mathrm{O}_{2}$ if this latter is equal to the production rate of ${ }^{16} \mathrm{O}_{2}$.

\section{Results and discussion}

\subsection{Characterizations}

\subsubsection{Texture characterizations}

The support granulometry, SSA, pores size and pore volumes of the different catalysts are summarized in Table 2. YSZ and $\mathrm{ZrO}_{2}$, both

Table 2

Textural properties of catalysts after calcination at $700{ }^{\circ} \mathrm{C}$ and hydrothermal ageing.

\begin{tabular}{|c|c|c|c|c|c|c|}
\hline \multirow[t]{2}{*}{ Catalysts } & \multicolumn{2}{|c|}{$\begin{array}{l}\text { Specific surface area } \\
\left(\mathrm{m}^{2} / \mathrm{g}\right)\end{array}$} & \multicolumn{2}{|c|}{$\begin{array}{l}\text { Porous volume } \\
\left(\mathrm{cm}^{3} / \mathrm{g}\right)\end{array}$} & \multicolumn{2}{|l|}{$\begin{array}{l}\text { Pores size } \\
(\mathrm{nm})\end{array}$} \\
\hline & Calcined & Aged & Calcined & Aged & Calcined & Aged \\
\hline 1Ag/YSZ & 12 & 7 & 0.04 & 0.01 & $2.3 / 30$ & 7 \\
\hline $1 \mathrm{Ag} / \mathrm{YSZb}$ & 6 & 4 & 0.02 & 0.01 & 12 & 7 \\
\hline $1 \mathrm{Ag} / \mathrm{ZrO}_{2}$ & 12 & 6 & 0.06 & 0.01 & $2.3 / 40$ & 7 \\
\hline $1 \mathrm{Ag} / \mathrm{SiO}_{2}$ & 180 & 135 & 1.53 & 1.18 & 29 & 33 \\
\hline $1 \mathrm{Ag} / \mathrm{CZ}$ & 71 & 14 & 0.21 & 0.11 & $2.2 / 9$ & $2.3 / 40$ \\
\hline
\end{tabular}

manufactured by Tosoh by atomization method, display large spherical agglomerates with diameters in the range $20-160 \mu \mathrm{m}$ and a median diameter d50 of $68 \mu \mathrm{m}$. YSZb and $\mathrm{SiO}_{2}$ powders contain randomly shaped agglomerates, smaller than $3 \mu \mathrm{m}$ with a median diameter of $0.3 \mu \mathrm{m}$. $\mathrm{CZ}$ displays spherical agglomerates of average diameter with a d50 of $6 \mu \mathrm{m}$.

Both $\mathrm{SiO}_{2}$ and $\mathrm{CZ}$ based catalysts exhibit higher SSA values, (180 and $71 \mathrm{~m}^{2} / \mathrm{g}$, respectively) compared to zirconia based catalysts. Similarly, $1 \mathrm{Ag} / \mathrm{SiO}_{2}$ displays the highest pore volume followed by $1 \mathrm{Ag} / \mathrm{CZ}$. SSA and pore volume of $1 \mathrm{Ag} / \mathrm{YSZb}$ are the lowest among studied catalysts. All Ag-supported catalysts are mesoporous. The pore size distribution of $1 \mathrm{Ag} / \mathrm{YSZ}, 1 \mathrm{Ag} / \mathrm{ZrO}_{2}$ and $1 \mathrm{Ag} / \mathrm{CZ}$ is bimodal, showing small pores in the range $2.2-2.5 \mathrm{~nm}$ alongside with larger ones, of around $30-40 \mathrm{~nm}$ for zirconia based support and $9 \mathrm{~nm}$ for $1 \mathrm{Ag} / \mathrm{CZ}$. On the other hand, $\mathrm{Ag} /$ YSZb only contains one medium pore size of around $12 \mathrm{~nm}$. The sample $1 \mathrm{Ag} / \mathrm{SiO}_{2}$ displays the biggest medium pore size of $29 \mathrm{~nm}$.

As expected, after hydrothermal ageing, we notice a general drop of samples SSA and pore volume (Table 2). $1 \mathrm{Ag} / \mathrm{CZ}$ is the most impacted catalyst with SSA dropping from 71 to $14 \mathrm{~m}^{2} / \mathrm{g}$ and pore volume from 0.21 to $0.11 \mathrm{~cm}^{3} / \mathrm{g}$. Larger pores of $40 \mathrm{~nm}$ are detected which might result from initial $9 \mathrm{~nm}$ pores crumbling. The SSA and the pore volume of $1 \mathrm{Ag} / \mathrm{SiO}_{2}$ are reduced but still remain one order of magnitude higher than those of other catalysts. The texture of $1 \mathrm{Ag} / \mathrm{YSZ}$ and $1 \mathrm{Ag} / \mathrm{ZrO}{ }_{2}$ follows similar evolution resulting in a reduced SSA and a diminution of both the volume and the size of the pores. The pore size distribution becomes unimodal upon ageing with a mean pore diameter of around $7 \mathrm{~nm}$. Interesting to note that $1 \mathrm{Ag} / \mathrm{YSZb}$ exhibits the best thermal stability.

\subsubsection{Silver loading on calcined and aged catalysts}

Calcined catalysts contain a silver loading ranging from 1 to $1.3 \mathrm{wt}$ $\%$, while the theoretical one was $1.3 \mathrm{wt} \%$. In addition, after hydrothermal ageing, we observed a drop in the Ag content, due to the high vapor pressure of $\mathrm{Ag}$ (melting point at $961^{\circ} \mathrm{C}$ ). The $\mathrm{Ag}$ loss after ageing (Table 1) strongly depends on the nature of the support. The Ag loss is small, only 7 and $8 \%$ on $\mathrm{SiO}_{2}$ and YSZb, respectively whereas it is significant on $\mathrm{YSZ}, \mathrm{ZrO}_{2}$ and CZ. Interestingly, the percentage of $\mathrm{Ag}$ loss follows the same rank than the $\mathrm{Ag}$ loading in the calcined catalysts (Table 1). This indicates that Ag loss most probably also takes place during the calcination step at $700{ }^{\circ} \mathrm{C}$ and is particularly pronounced on $\mathrm{CZ}, \mathrm{ZrO}_{2}$ on YSZ. This explains the lower Ag loading measured on these supports after calcination. For instance, on $\mathrm{CZ}$, the Ag loading is only $1 \mathrm{wt} \%$, suggesting that almost $23 \%$ of the Ag NPs sublimated during the calcination step at $700{ }^{\circ} \mathrm{C}$. These results are in good agreement with those reported by Sun et al. [16] who observed, with TEM, the sublimation of Ag NPs supported on silica from $600^{\circ} \mathrm{C}$. TEM analysis also reveals that this phenomenon is more pronounced and faster on smallest Ag NPs located on the surface with respect to those anchored inside pores. This could indicate that Ag NPs are mainly located in the pores of YSZb and $\mathrm{SiO}_{2}$ in good agreement with the absence of small $2 \mathrm{~nm}$ size pores on these two supports contrary to all other oxides.

\subsubsection{Structure characterizations}

XRD analysis were carried out to check the stability of the support structure after the hydrothermal ageing and to estimate the crystallite size of $\mathrm{Ag}$ NPs. Both $1 \mathrm{Ag} / \mathrm{YSZ}$ and $1 \mathrm{Ag} / \mathrm{YSZd}$ can be indexed as a pure fluorite cubic phase and $1 \mathrm{Ag} / \mathrm{CZ}$ as a cubic phase. $1 \mathrm{Ag} / \mathrm{ZrO}_{2}$ displays a predominant monoclinic phase (Fig. 1). No modification of supports structure was detected after ageing. After hydrothermal ageing, the sintering of the support is observed mostly over $1 \mathrm{Ag} / \mathrm{CZ}$ as diffraction peaks become sharper and corresponding intensities increase in good agreement with SSA measurements. As expected, $\mathrm{SiO}_{2}$ is amorphous.

Whatever the nature of the support, only metallic silver has been detected on the diffractograms in good agreement with previous studies over Ag NPs supported on $\mathrm{ZrO}_{2}, \mathrm{CeO}_{2}, \mathrm{Al}_{2} \mathrm{O}_{3}$ and $\mathrm{SiO}_{2}$ [17-21]. Nevertheless, intensities of the metallic silver diffraction peaks $\left(38.1^{\circ}\right.$, 

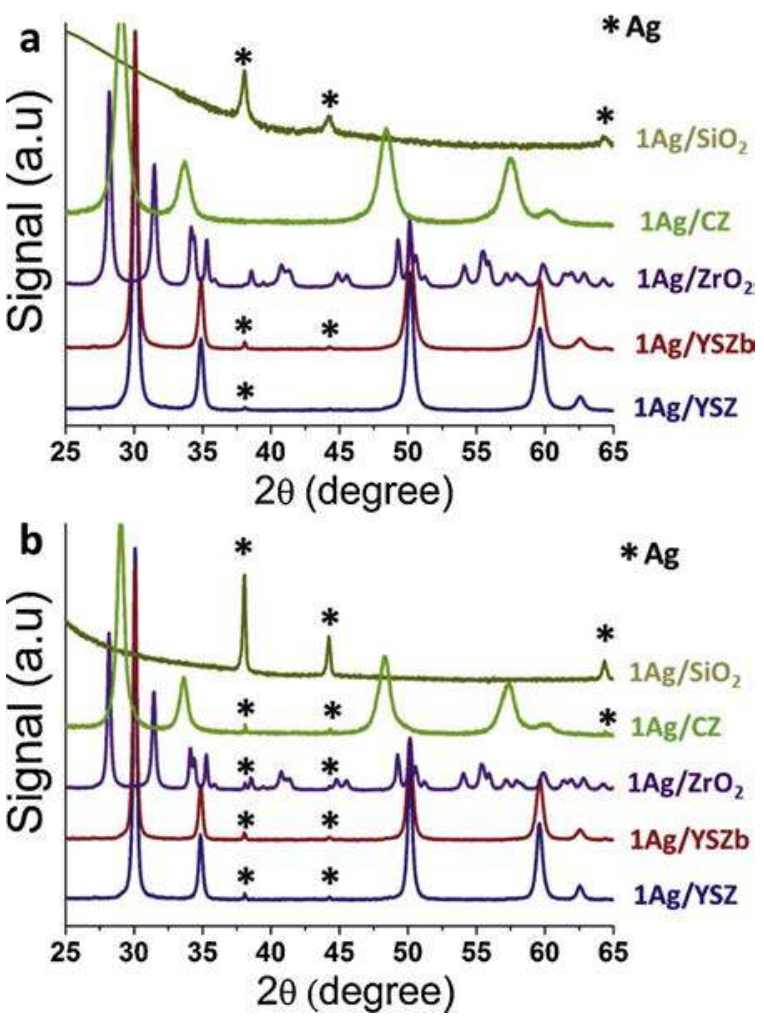

Fig. 1. Silver supported catalysts diffractograms, a) after calcination, b) after hydrothermal ageing.

$44.3^{\circ}$ and $64.5^{\circ}$, JCPDS \# 04-0783) are low for all catalysts. Furthermore, no peak corresponding to $\mathrm{Ag}^{\circ}$ can be detected on calcined $1 \mathrm{Ag} / \mathrm{CZ}$. This could indicate a high Ag dispersion on CZ. On calcined $1 \mathrm{Ag} / \mathrm{ZrO}_{2}$, the diffraction peak at $38.1^{\circ}$ of $\mathrm{Ag}^{\circ}$ is hidden by the support diffraction pattern. Therefore, intensities of the $\mathrm{Ag}^{\circ}$ diffraction peaks only allow an estimation of Ag NPs crystallite size when dispersed on YSZ, YSZb and $\mathrm{SiO}_{2}$ (Table 1). Average Ag NPs crystallites sizes are similar over both kinds of YSZ, of around $30 \mathrm{~nm}$. As expected from its much higher $\mathrm{SSA}, 1 \mathrm{Ag} / \mathrm{SiO}_{2}$ displays smaller $\mathrm{Ag}$ NPs crystallite size $(16 \mathrm{~nm})$. Smallest sizes between 10 and $20 \mathrm{~nm}$ are reported in the literature data $[20,22,23]$ from XRD analysis but this can be explained by lower calcination temperatures $\left(500^{\circ} \mathrm{C}\right.$ or $\left.600^{\circ} \mathrm{C}\right)$. After hydrothermal treatment, the $\mathrm{XRD}$ peaks of $\mathrm{Ag}^{\circ}$ are detectable over all catalysts.
Peaks are high enough to perform an estimation of the Ag NPs size from the Scherrer calculation except for $1 \mathrm{Ag} / \mathrm{CZ}$. This could be related to the high silver loss (Table 1 ). Sintering is observed for $1 \mathrm{Ag} / \mathrm{YSZ}$ and $1 \mathrm{Ag} / \mathrm{YSZb}$ with an average crystallite size increased by $50 \%$ and reaching $50 \mathrm{~nm}$. Slightly higher value is obtained for $1 \mathrm{Ag} / \mathrm{ZrO}_{2}$ with $61 \mathrm{~nm}$. Sintering over $1 \mathrm{Ag} / \mathrm{SiO}_{2}$ appears to be more severe with an average silver crystallite size doubled after ageing $(36 \mathrm{~nm})$. Sintering starting from $400{ }^{\circ} \mathrm{C}$ was reported by Sun et al. for Ag NPs supported over $\mathrm{SiO}_{2}$ [16]. Moulijn et al. [24] reported that metal particles mobility can be observed at the Hüttig temperature corresponding to $0.3 \mathrm{~T}_{\text {melting. }}$. At this temperature, which corresponds to $320^{\circ} \mathrm{C}$ in the case of metallic silver, atoms located at the edge and defect of the NPs become mobiles. Bulk mobility is reached at the Tamman temperature corresponding to $0.5 \mathrm{~T}_{\text {melting }}\left(480^{\circ} \mathrm{C}\right)$, leading to coalescence phenomena.

\subsubsection{TEM characterizations}

TEM observations were performed over all catalysts, after calcination and ageing (Fig. 2). Contrast between support and Ag NPs is rather weak for zirconia-based catalysts and for $1 \mathrm{Ag} / \mathrm{CZ}$. This is related to atomic numbers of $\mathrm{Ag}(47)$ and $\mathrm{Zr}$ (40) being similar. Such low contrast results in large Ag NPs being confounded with supports grains. Thus, calculated size distributions might mainly focus on the smaller and surface particles $(<20 \mathrm{~nm})$. Furthermore, in the case of $1 \mathrm{Ag} / \mathrm{CZ}, \mathrm{Ag} \mathrm{NPs}$ are too small to be easily discernable from the support and no clear conclusion can be drawn on size and shape of Ag NPs on CZ. TEM observations on the other samples indicate that Ag NPs are round-shaped. $\mathrm{Ag}$ NPs size distribution is wide whatever the calcined catalyst, ranging from $3 \mathrm{~nm}$ to more than $30 \mathrm{~nm}$ (Fig. $3 \mathrm{a}$ ). $1 \mathrm{Ag} / \mathrm{YSZ}$ and $1 \mathrm{Ag} / \mathrm{ZrO}_{2}$ display slightly more numerous smaller particles (distribution centered on $8 \mathrm{~nm}$ ), while $1 \mathrm{Ag} / \mathrm{YSZb}$ and $1 \mathrm{Ag} / \mathrm{SiO}_{2}$ show a distribution centered on $10 \mathrm{~nm}$, which extends to larger diameters. This size differs from the one obtained in XRD on zirconia-based catalysts (Table 1), which is around $35 \mathrm{~nm}$. This can be explained by XRD being a volumetric analysis, sensitive to the overall amount of silver, while TEM observations only focus on the discernible surface small particles. Similar difference between XRD analysis and TEM observations was already reported in the literature by Kundakovic and Flytzani-Stephanopoulos for silver-supported zirconia calcined at $650^{\circ} \mathrm{C}$ [19]. Authors concluded on the coexistence of numerous smaller particles (in the $5 \mathrm{~nm}$ range) along with bigger ones $(>30 \mathrm{~nm})$. Similar conclusion can be drawn from XRD and TEM data and one can assume that Ag NPs on zirconia-based catalysts display a bimodal size distribution centered on 8-10 nm for the smaller ones and on $40 \mathrm{~nm}$ for the largest. Over $1 \mathrm{Ag} / \mathrm{SiO}_{2}$ where contrast does not impact Ag NPs detection, XRD and TEM observations match more

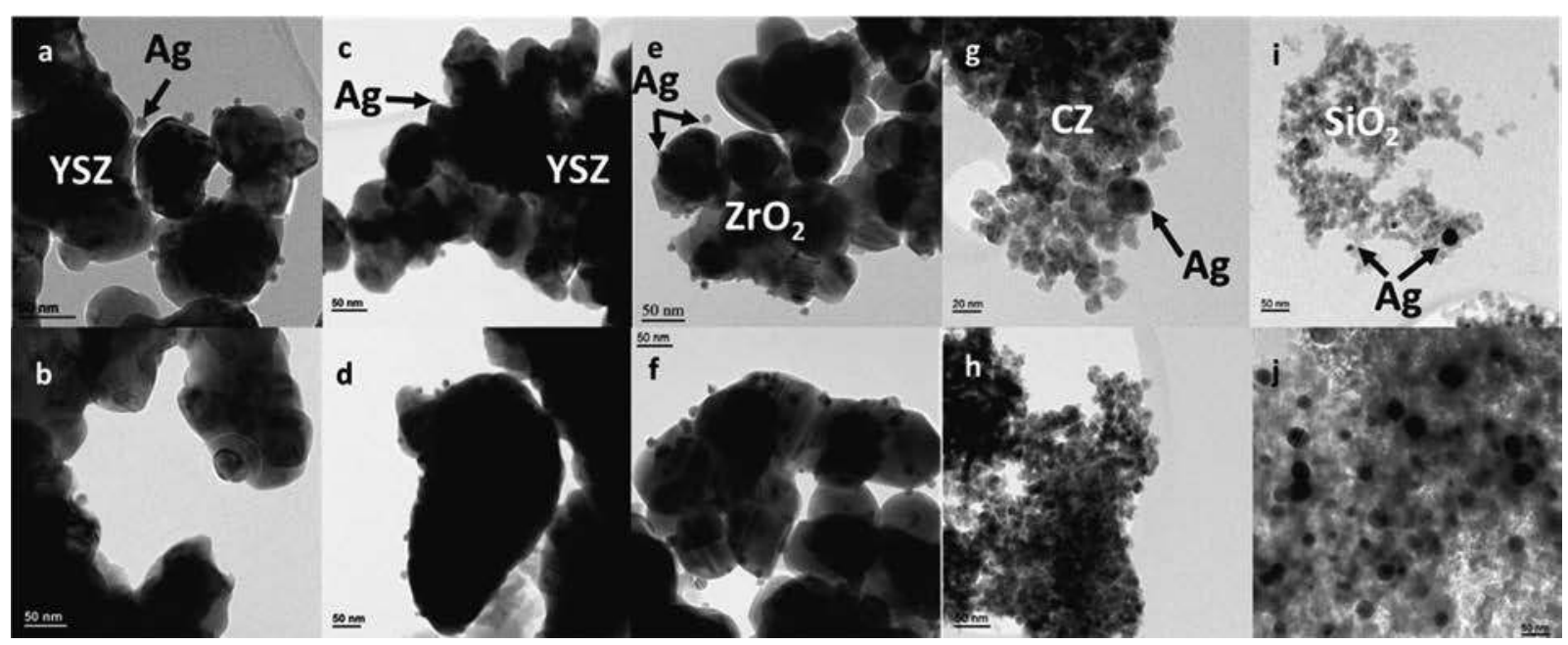

Fig. 2. TEM micrographs of a) $1 \mathrm{Ag} / \mathrm{YSZ}$, b) aged $1 \mathrm{Ag} / \mathrm{YSZ}$, c) $1 \mathrm{Ag} / \mathrm{YSZb}$, d) aged $1 \mathrm{Ag} / \mathrm{YSZb}$, e) $1 \mathrm{Ag} / \mathrm{ZrO}$, f) aged $1 \mathrm{Ag} / \mathrm{ZrO}$, g) $1 \mathrm{Ag} / \mathrm{CZ}, \mathrm{h}) \mathrm{aged} 1 \mathrm{Ag} / \mathrm{CZ}$, i) $1 \mathrm{Ag} /$ $\mathrm{SiO}_{2}, j$ ) aged $1 \mathrm{Ag} / \mathrm{SiO}_{2}$. 
a

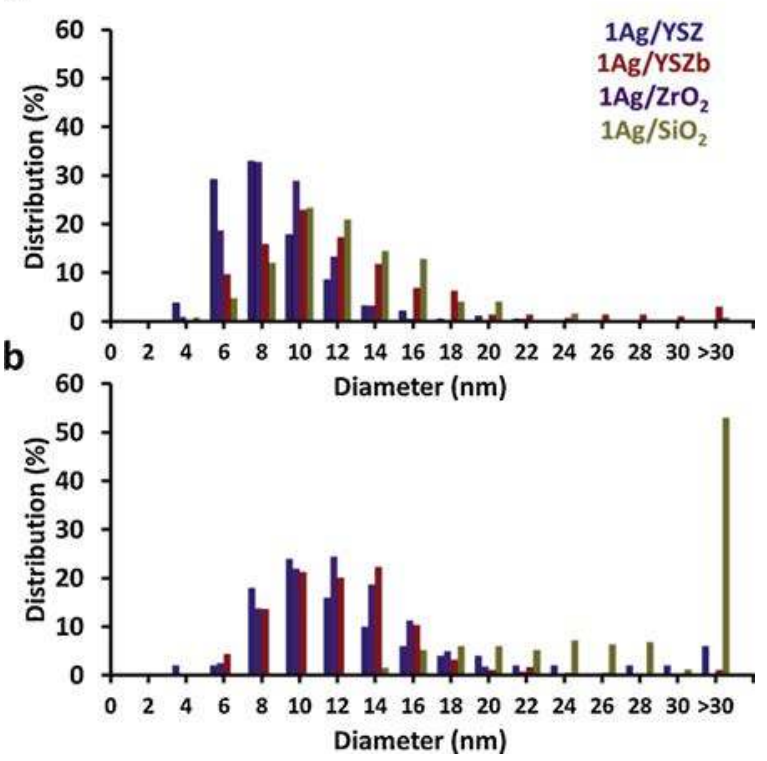

Fig. 3. Ag NPs diameter distribution observed by TEM, a) calcined catalysts, b) aged catalysts.

closely: 16 and $10 \mathrm{~nm}$ with XRD and TEM, respectively.

Upon ageing, all distributions are shifted toward largest sizes (Fig. 3b). Zirconia-based catalysts still contain Ag NPs smaller than $15 \mathrm{~nm}$ (accounting for $70 \%$ of the distribution). Bimodal distribution is maintained with diameters in the range $10-12 \mathrm{~nm}$ for small particles while bigger particles measured by XRD ranges from 50 to $60 \mathrm{~nm}$ for these samples. Ageing impact is mostly detectable over $1 \mathrm{Ag} / \mathrm{SiO}_{2}$ as $\mathrm{Ag}$ NPs are mainly larger than $30 \mathrm{~nm}$ (55\% of the distribution) without any particles smaller than $14 \mathrm{~nm}$. This result is in good agreement with XRD (Table 1).

\subsubsection{Surface characterizations}

Ratios between the surface, determined by XPS, and volume, measured by ICP, Ag atomic percentage give a good indication of the surface Ag concentration (Table 3). Zirconia-based catalysts exhibit a surface segregation of $\mathrm{Ag}$ at ratios are larger than 1 (Table 3). This trend is much more pronounced on YSZ and $\mathrm{ZrO}_{2}$. This indicates that Ag NPS are mainly located on the surface. On the other hand, silver is slightly less present at the outer surface than over the whole volume on CZ, indicating that some Ag NPs might be present in the pores. Similarly, $1 \mathrm{Ag} / \mathrm{SiO}_{2}$ displays very low fraction of $\mathrm{Ag}$ on its surface in good accordance with its high pore volume. After ageing, the fraction of Ag NPs on the surface was found to be stable on YSZb whereas on YSZ it drops by a factor 2.5. Such results follow the same trend than the Ag loss, indicating that remaining Ag NPs on YSZ after ageing are mainly located in the pores. Similar correlation between Ag loss and Ag surface concentration diminution is observed for $1 \mathrm{Ag} / \mathrm{ZrO}_{2}$ upon ageing, even if on this support, a $\mathrm{Ag}$ surface segregation still exists. On $\mathrm{SiO}_{2}$, the atomic

Table 3

XPS analysis of silver supported catalysts, silver and yttria atomic surface to volume ratio.

\begin{tabular}{llllll}
\hline \multirow{2}{*}{ Catalysts } & \multicolumn{2}{l}{$\begin{array}{l}\text { Silver surface to volume atomic } \\
\text { ratio }\end{array}$} & & \multicolumn{2}{l}{$\begin{array}{l}\text { Y/Zr surface to volume atomic } \\
\text { ratio }\end{array}$} \\
\cline { 2 - 3 } \cline { 5 - 6 } & calcined & aged & & calcined & aged \\
\hline $1 \mathrm{Ag} / \mathrm{YSZ}$ & 1.57 & 0.62 & 1.27 & 1.5 & 1.6 \\
$1 \mathrm{Ag} / \mathrm{YSZb}$ & 1.30 & 1.36 & 1.3 & 1.6 \\
$1 \mathrm{Ag} / \mathrm{ZrO}_{2}$ & 1.59 & 0.07 & - & - \\
$1 \mathrm{Ag} / \mathrm{SiO}_{2}$ & 0.19 & 0.37 & - & - \\
$1 \mathrm{Ag} / \mathrm{CZ}$ & 0.89 & 1.37 & - & - \\
\hline
\end{tabular}

fraction of Ag NPs on the surface becomes negligible after ageing, demonstrating that large Ag NPs observed by TEM are mainly covered by silica.

$1 \mathrm{Ag} / \mathrm{CZ}$ displays higher surface $\mathrm{Ag}$ atomic fraction upon ageing while its SSA, pore volume and Ag loading drastically drop. A hypothesis would be that Ag NPs contained within the pores are expelled during ageing and remain small, maintaining a good dispersion.

In the case of $1 \mathrm{Ag} / \mathrm{YSZ}$ and $1 \mathrm{Ag} / \mathrm{YSZb}, \mathrm{Y} / \mathrm{Zr}$ surface to volume atomic ratios have been extracted from XPS experiments. They represent the concentration gradient of yttrium between the surface and the bulk. Both $1 \mathrm{Ag} / \mathrm{YSZ}$ and $1 \mathrm{Ag} / \mathrm{YSZb}$ catalysts display a surface segregation of yttrium. Such effect has already be reported in the literature for Tosoh YSZ $[11,25]$. The surface yttrium segregation is more pronounced on YSZ. Therefore, different surface properties are expected between $1 \mathrm{Ag} / \mathrm{YSZ}$ and $1 \mathrm{Ag} / \mathrm{YSZb}$. For instance, the surface oxygen vacancies concentration is supposed to be higher on YSZ than on YSZb, on the opposite of the concentration of acidic sites. Upon ageing, $\mathrm{Y}^{3+}$ segregation increases for both $1 \mathrm{Ag} / \mathrm{YSZ}$ and $1 \mathrm{Ag} / \mathrm{YSZb}, \mathrm{Y} / \mathrm{Zr}$ ratio reaches 1.6. This increase is more pronounced over $1 \mathrm{Ag} / \mathrm{YSZb}$ (initial ratio of 1.3) than over $1 \mathrm{Ag} / \mathrm{YSZ}$ (1.5), indicating a significant diffusion of yttrium on surface on YSZb during the hydrothermal treatment.

XPS analysis have also shown, for all Ag supported catalysts, that the $\mathrm{Ag} 3 \mathrm{~d}_{5 / 2}$ binding energy peak is centered below $368 \mathrm{eV}$ (Fig. S1), corresponding to $\mathrm{Ag}^{+}$ions. As the average silver particle size rage is 15-40 $\mathrm{nm}$ according to XRD data, one can assume that the top layer of the nanoparticles is mainly composed of silver oxides which are reduced during TPR but are not detected by XRD measurements.

\subsubsection{UV-vis spectroscopy}

UV-vis analysis were performed over bare supports and silversupported catalysts in air at RT in $200-800 \mathrm{~nm}$ domain on the calcined catalysts (Fig. 4). Difference between the two series of spectra underlines the absorption bands relative to Ag NPs. UV spectra recorded on zirconia based catalysts evidence cationic Ag clusters (absorption band at $250 \mathrm{~nm}[18,19]$ ) and metallic clusters and aggregates (bands at $320 \mathrm{~nm}$ and beyond $400 \mathrm{~nm}[30,34,18,19,26,27])$. Absorption difference is stronger for $1 \mathrm{Ag} / \mathrm{YSZ}$ and $1 \mathrm{Ag} / \mathrm{YSZb}$ beyond $320 \mathrm{~nm}$ which would imply that metallic silver particles are more present than over $1 \mathrm{Ag} / \mathrm{ZrO}{ }_{2}$. Similarly, Kundakovic and Flytzani-Stephanopoulos also reported the presence of both metallic silver and oxide silver (the latter possibly covering metallic silver) on silver-supported zirconia prepared by impregnation followed by calcination at $650^{\circ} \mathrm{C}$ for $8 \mathrm{~h}$ [19].

The UV spectra difference between that of $1 \mathrm{Ag} / \mathrm{CZ}$ and $\mathrm{CZ}$ clearly displays an intense absorption band at $200 \mathrm{~nm}$, representative of isolated $\mathrm{Ag}^{+}$ions $[18,26]$. A second absorption domain in the $360-460 \mathrm{~nm}$ range demonstrates the presence of metallic silver with metallic agglomerates. Presence of isolated $\mathrm{Ag}^{+}$ions are in good agreement with the absence of silver peaks detected in $\mathrm{XRD}$, which indicates a high

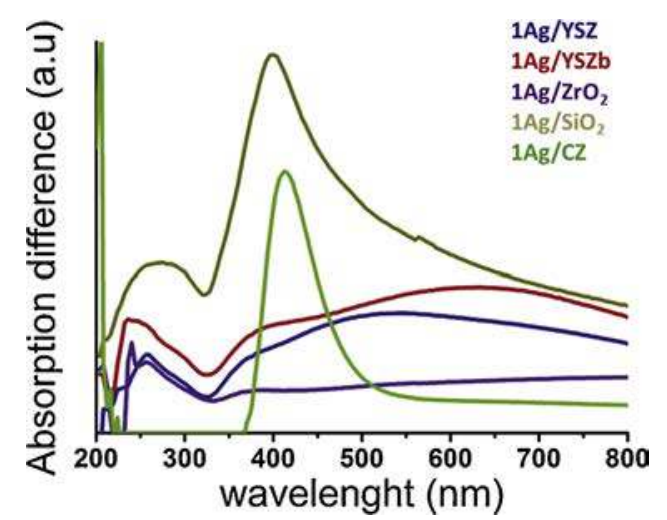

Fig. 4. UV-vis absorption difference between supports and silver-supported catalysts recorded in air at RT. 
dispersion of silver.

Absorption bands at $250-300 \mathrm{~nm}$ and in the $340-450 \mathrm{~nm}$ range are detected over $1 \mathrm{Ag} / \mathrm{SiO}_{2}$. These indicate the presence of both cationic and metallic clusters and aggregates, as for zirconia-based catalysts. Corro et al. [18] have done similar UV-vis analysis over $\mathrm{Ag} / \mathrm{SiO}_{2}$ calcined at $450^{\circ} \mathrm{C}$ for $6 \mathrm{~h}$ prior and after reduction in $\mathrm{H}_{2}$ at $500^{\circ} \mathrm{C}$. They have shown that calcined $\mathrm{Ag} / \mathrm{SiO}_{2}$ mostly contained $\mathrm{Ag}^{+}$isolated ions, while the reduction mostly formed metallic clusters. As our sample was calcined at much higher temperature $\left(700^{\circ} \mathrm{C}\right)$, one can expect that isolated $\mathrm{Ag}^{+}$ions have coalesced, leading to bigger agglomerates, possibly displaying both metallic and oxide phases. This hypothesis correlates the average Ag NPs size detected by TEM and XRD: 10 and $16 \mathrm{~nm}$ respectively.

\subsubsection{Reducibility of the Ag-supported catalysts}

Reducibility of the calcined samples was investigated by running TPR (Fig. 5). Spectra display a $\mathrm{H}_{2}$ consumption in a broad temperature range between $50^{\circ} \mathrm{C}$ and $300^{\circ} \mathrm{C}$ except for $1 \mathrm{Ag} / \mathrm{CZ}$ due to the reduction of $\mathrm{CZ}$ from around $250^{\circ} \mathrm{C}$ [28]. Various $\mathrm{H}_{2}$ consumption peaks are observed at $75^{\circ} \mathrm{C}, 140^{\circ} \mathrm{C}$ and around $250^{\circ} \mathrm{C}$ indicating that different reducible $\mathrm{AgO}_{\mathrm{x}}$ species are present over the catalysts surface in good agreement with similar experiments reported in the literature for $\mathrm{Ag}$ supported on $\mathrm{SiO}_{2}$ [29], $\mathrm{Al}_{2} \mathrm{O}_{3}$ [27], $\mathrm{ZrO}_{2}$ [30] and $\mathrm{CeO}_{2}$ [31,32]. Reduction peaks were associated with $\mathrm{Ag}_{2} \mathrm{O}$ particles and well-dispersed $\mathrm{Ag}^{+}$species or oxidized silver clusters. Reduction peaks in the temperature range $60-110^{\circ} \mathrm{C}$ were obtained for a $10 \% \mathrm{Ag} / \mathrm{CeO}_{2}$ catalyst calcined at $400{ }^{\circ} \mathrm{C}$ during reduction under $5 \% \mathrm{H}_{2} / \mathrm{He}$ [32]. First reduction peak was associated with $\mathrm{AgO}$ reduction to $\mathrm{Ag}_{2} \mathrm{O}$ and second one corresponded to $\mathrm{Ag}_{2} \mathrm{O}$ reduction to metallic Ag. The smaller the $\mathrm{Ag}_{2} \mathrm{O}$ particles, the higher the reduction temperature. Therefore, the shifted reduction of $1 \mathrm{Ag} / \mathrm{CZ}$ to higher temperatures compared to the other catalysts indicates that this sample contains smaller AgOx NPs. Regarding the other catalysts, the wide temperature domain of the samples reduction as well as the presence of several overlapped peaks suggest that silver oxide is present at the catalyst surface under different forms and sizes, as already shown by UV-vis spectroscopy. The overall amount of $\mathrm{H}_{2}$ consumption has been estimated by integrating the TPR spectra between room temperature and $300^{\circ} \mathrm{C}$. Samples $1 \mathrm{Ag} / \mathrm{YSZ}$, $1 \mathrm{Ag} / \mathrm{ZrO}_{2}$ and $1 \mathrm{Ag} / \mathrm{SiO}_{2}$ display similar $\mathrm{H}_{2}$ consumption larger than that observed on $1 \mathrm{Ag} / \mathrm{YSZb}$. More interesting, the $\mathrm{H}_{2} / \mathrm{Ag}$ molar ratio is 3 times lower on $1 \mathrm{Ag} / \mathrm{YSZb}$ than on $1 \mathrm{Ag} / \mathrm{YSZ}$ (Fig. 5, Table 4). This indicates that $1 \mathrm{Ag} / \mathrm{YSZb}$ contains the lowest amount of silver oxide species while, on the opposite, YSZ seems to stabilize the largest amount of $\mathrm{AgO}_{\mathrm{x}}$. Ag NPs size distribution indicates that $1 \mathrm{Ag} / \mathrm{YSZ}$ display smaller

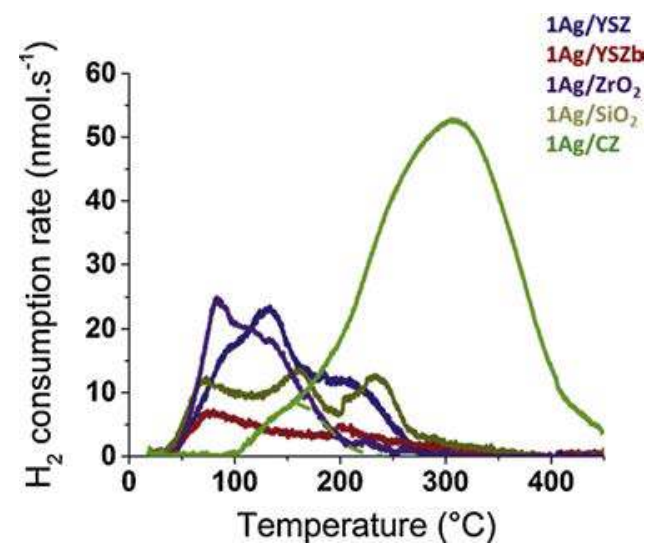

Fig. 5. $\mathrm{H}_{2}$ consumption rate with respect to temperature during TPR experiments under $1 \% \mathrm{H}_{2} / \mathrm{He}$. blue: $1 \mathrm{Ag} / \mathrm{YSZ}$, red: $1 \mathrm{Ag} / \mathrm{YSZb}$, brown: $1 \mathrm{Ag} / \mathrm{SiO}_{2}$, purple: $1 \mathrm{Ag} / \mathrm{ZrO}_{2}$, green: $1 \mathrm{Ag} / \mathrm{CZ}$. (For interpretation of the references to colour in this figure legend, the reader is referred to the web version of this article).
Table 4

Consumed amounts of $\mathrm{H}_{2}$ during TPR, ratio of consumed hydrogen by total amount of silver on the catalyst (*shoulder fitted by the dotted line).

\begin{tabular}{lll}
\hline Catalysts & $\begin{array}{l}\mathrm{n} \mathrm{H}_{2} \text { consumed } \\
(\mu \mathrm{mol})\end{array}$ & $\mathrm{H}_{2} / \mathrm{Ag}$ total \\
\hline $1 \mathrm{Ag} / \mathrm{YSZ}$ & 14 & 0.46 \\
$1 \mathrm{Ag} / \mathrm{YSZb}$ & 5 & 0.16 \\
$1 \mathrm{Ag} / \mathrm{ZrO}_{2}$ & 10 & 0.32 \\
$1 \mathrm{Ag} / \mathrm{SiO}_{2}$ & 11 & 0.3 \\
$1 \mathrm{Ag} / \mathrm{CZ}$ & $3^{\mathrm{a}}$ & $0.11^{\mathrm{a}}$ \\
\hline
\end{tabular}

a Shoulder fitted by the dotted line in Fig. 4.

particles which are more proned to be oxidized, thus leading to higher amount of consumed $\mathrm{H}_{2}$ during reduction. As observed in UV-vis and TEM, $1 \mathrm{Ag} / \mathrm{SiO}_{2}$ displays cationic silver clusters and $\mathrm{Ag}$ NPs of various sizes which would explain the overall $\mathrm{H}_{2}$ consumption over a wide temperature range. Presence of well-dispersed $\mathrm{Ag}^{+}$species over $1 \mathrm{Ag} / \mathrm{CZ}$ was detected by UV-VIS analysis, reduction of such species corresponds to the $\mathrm{H}_{2}$ consumption shoulder between 100 and $160^{\circ} \mathrm{C}$ indicated by the dotted line in Fig. 5.

\subsection{Temperature programmed isotopic exchange (TPIE)}

To assess silver effect toward surface oxygen exchange, we performed TPIE experiments over all calcined catalysts. In presence of silver, oxygen exchange starts in the range $310-330^{\circ} \mathrm{C}$ with the exception of $1 \mathrm{Ag} / \mathrm{SiO}_{2}$ where exchange begins from $450{ }^{\circ} \mathrm{C} \mathrm{(Fig.} \mathrm{6).} \mathrm{Over} \mathrm{zirconia-}$ based bare supports, exchange starts at $540{ }^{\circ} \mathrm{C}$ (Fig. S2) as recently observed on YSZ [11]. However, different exchange rates are observed following the order YSZb $>\mathrm{ZrO}_{2}>$ YSZ.

Silver is shown to greatly activate oxygen exchange, lowering the exchange temperature by as much as $230^{\circ} \mathrm{C}$ in good agreement with recent results [11]. Exchange occurs through multiple heteroexchange, producing only ${ }^{16} \mathrm{O}_{2}$ during the first minutes of the experiments:

${ }^{18} \mathrm{O}^{18} \mathrm{O}(\mathrm{g})+2{ }^{16} \mathrm{O}(\mathrm{s}) \rightarrow{ }^{16} \mathrm{O}_{2}(\mathrm{~g})+2{ }^{18} \mathrm{O}(\mathrm{s})$

TPIE experiments performed over bare zirconia-based oxides (Fig. S1) indicated that exchange occurred through both simple and multiple heteroexchanges which correlates with similar observations reported by $\mathrm{Zhu}$ et al. over $\mathrm{YSZ}$ and $\mathrm{ZrO}_{2}$ [33]. Weak oxygen exchange over bare $\mathrm{SiO}_{2}$ was also reported by Martin et Duprez over $650{ }^{\circ} \mathrm{C}$ [34]. In the presence of silver, oxygen exchange is rather limited and occurs only from $450^{\circ} \mathrm{C}$.

In the presence of $\mathrm{Ag}$, zirconia based samples initiate oxygen exchange at similar temperatures from 310 to $320^{\circ} \mathrm{C}$ (Fig. 6). This clearly confirms that below $500^{\circ} \mathrm{C}$, the oxygen exchange only occurs on Ag NPs. Martin et Duprez reported that $\mathrm{Rh}$ particles size dispersed on $\mathrm{ZrO}_{2}, \mathrm{CZ}$ and $\mathrm{SiO}_{2}$ was also driving the exchange rate, a lower particles size leading to an increased exchange rate [34]. Oxygen exchange rates have been compared at $400{ }^{\circ} \mathrm{C}$ as, at this temperature, no ${ }^{16} \mathrm{O}^{18} \mathrm{O}$ oxygen species are in the gas phase. They are quite similar when Ag NPs are dispersed on $\mathrm{ZrO}_{2}$, YSZb and $\mathrm{CZ}$ and twice lower on YSZ but still in the same order of magnitude. Therefore, the nature of the support does not seem to significantly influence the surface oxygen exchange at $400{ }^{\circ} \mathrm{C}$ which is driven by Ag NPs. Rate difference between $1 \mathrm{Ag} / \mathrm{YSZ}$ and $1 \mathrm{Ag} / \mathrm{YSZb}$ could originate from the larger yttrium surface concentration measured over $1 \mathrm{Ag} / \mathrm{YSZ}$. We have recently shown [11] that carbonation occurs over YSZ, preferentially over $\mathrm{Y}^{3+}$ Lewis basic sites. Surface carbonation would lead to adsorption sites being blocked, hence limiting the oxygen exchange rate. On the other hand, amounts of exchanged bulk oxygens $\left({ }^{16} \mathrm{O}\right)$ upon completion of the TPIE depend on the nature of the support. They are similar for both $1 \mathrm{Ag} / \mathrm{YSZ}$ and $1 \mathrm{Ag} / \mathrm{ZrO}_{2}$. However, $1 \mathrm{Ag} / \mathrm{YSZb}$ displays higher exchanged amounts of $15 \%$ instead of around $10 \%$ on $1 \mathrm{Ag} / \mathrm{YSZ}$ and $1 \mathrm{Ag} / \mathrm{ZrO}_{2}$. This indicates that the bulk oxygen mobility is higher in YSZb than on $\mathrm{YSZ}$ and $\mathrm{ZrO}_{2}$, in good agreement 

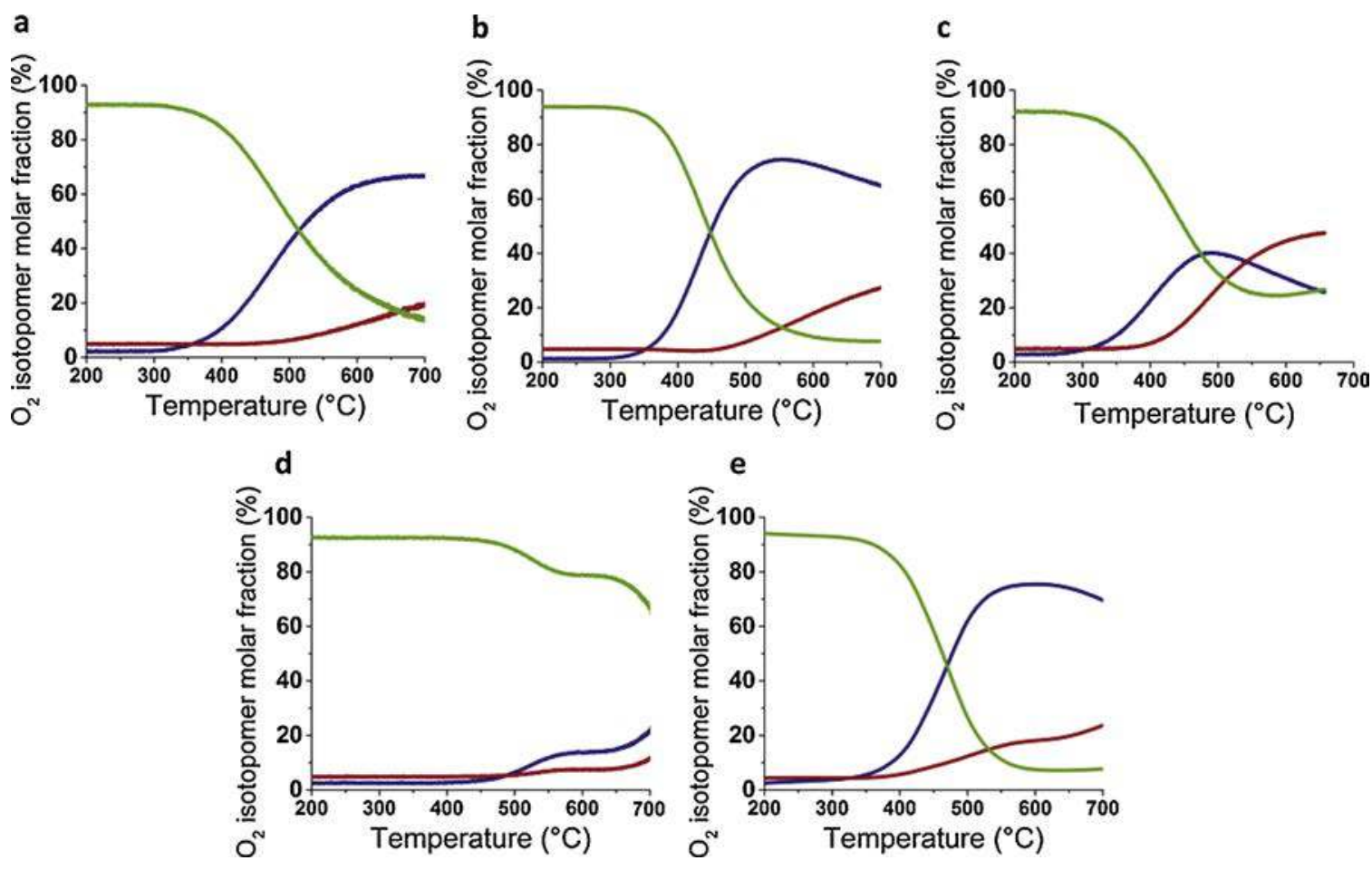

Fig. 6. $\mathrm{O}_{2}$ isotopomers molar fraction with respect to temperatures during TPIE experiments. Green line: ${ }^{18} \mathrm{O}_{2}$, red line: ${ }^{18} \mathrm{O}^{16} \mathrm{O}$, blue line: ${ }^{16} \mathrm{O}$. a) $1 \mathrm{Ag} / \mathrm{YSZ}$, b) $1 \mathrm{Ag} /$ YSZb, c) $1 \mathrm{Ag} / \mathrm{ZrO}{ }_{2}$, d) $1 \mathrm{Ag} / \mathrm{SiO}_{2}$, e) $1 \mathrm{Ag} / \mathrm{CZ}$. (For interpretation of the references to colour in this figure legend, the reader is referred to the web version of this article).

with the faster oxygen exchange rate observed on bare supports (Fig. S1). On $1 \mathrm{Ag} / \mathrm{CZ}$, the fraction of exchanged bulk oxygen species achieves $28.2 \%$, most probably due to the high reducibility of $\mathrm{CZ}$ at $400{ }^{\circ} \mathrm{C}$ as confirmed by TPR (Fig. 5).

Soot oxidation over YSZ occurs through lattice oxygen species provided by YSZ [9]. YSZ being not reducible, we demonstrated that the limiting step of the oxidation reaction was the oxygen replenishment of YSZ lattice by the gas phase, occurring at the tpb soot/YSZ/gas in the absence of silver. This process is similar to the electrochemical reduction of oxygen in solid state electrochemical cells. Ag electrode is well-known to be one the most active for oxygen electrochemical reaction [35,36]. This explains that the replenishment was found to be greatly promoted by the presence of Ag NPs [11], as confirmed during TPIE experiments (Fig. 6).

\subsection{Catalytic performances for carbon oxidation in supertight contact}

\subsubsection{Catalytic properties for propene cracking}

Evaluation of catalytic performances toward soot oxidation is known to be highly dependent on the contact quality between soot and catalyst [37]. Loose and tight contact modes as described earlier are commonly studied, although intimate "supertight" contact was only described recently by Aneggi et al. [38]. This latter study describes a high-energy milling of CZ powder and carbon soot resulted in a thin carbon envelope containing a core of oxide. We ought to study catalysts performance for carbon oxidation under similar "supertight" contact. To obtain nanometric carbon layers covered the catalyst surface, propene cracking was performed at $600{ }^{\circ} \mathrm{C}$ over both bare supports and silver supported catalysts for $30 \mathrm{~min}$. TPO was then performed to assess the amount of carbon deposited during cracking through the production of $\mathrm{CO}_{2}$ (Table 6). No production of $\mathrm{CO}$ was detected. Quantity of deposited carbon is low over YSZ, YSZb and $\mathrm{SiO}_{2}$ indicating a poor affinity of propene toward these supports. On the opposite, amounts measured over $\mathrm{ZrO}_{2}$ and $\mathrm{CZ}$ are 26 and 100 times higher than over YSZ, respectively. Taking into account the SSA of the supports (Table 6), one can distinguish three kinds of affinity between propene and support oxides: weak for YSZ and YSZb, strong for $\mathrm{ZrO}_{2}$ and $\mathrm{CZ}$ and negligible for $\mathrm{SiO}_{2}$. Carbon formation from propene cracking is dependent on the support acidity $[39,40]$, which promotes the propene adsorption. In the case of $\mathrm{ZrO}_{2}$, acidity originates from unsaturated $\mathrm{Zr}^{4+}$ sites at the surface [41]. Doping zirconia by silica or yttria was found to diminish the acidity [39, 42], hence explaining the lower amount of carbon deposited on YSZ and YSZb. Amount of deposited carbon with respect to the SSA was found to be $2.6 \mu \mathrm{mol} / \mathrm{m}^{2}$ for YSZb against $1.3 \mu \mathrm{mol} / \mathrm{m}^{2}$ for YSZ (Table 6). This correlates with the XPS data reported previously, YSZ displaying a higher $\mathrm{Y}^{3+}$ surface density than YSZb. Finally, amorphous $\mathrm{SiO}_{2}$ which does not exhibit any acidic sites cannot activate propene.

$\mathrm{Ag}$ NPs strongly promotes the propene adsorption and cracking over non-acidic supports. Enhancement is remarkable over 1Ag/YSZ and $1 \mathrm{Ag} / \mathrm{YSZb}$ as the amount of deposited carbon being increased almost tenfold. Carbon should be found on the oxide support and over the $\mathrm{Ag}$ NPs as the amount of deposited carbon exceeds the silver molar loading (Table 6). Smaller increase is noticeable on $1 \mathrm{Ag} / \mathrm{SiO}_{2}$. We suspect propene cracking only occurs in the silver particles vicinity as the molar carbon to $\mathrm{Ag}$ ratio is lower than 1 . Concerning acidic catalysts, $1 \mathrm{Ag}$ / $\mathrm{ZrO}_{2}$ and $1 \mathrm{Ag} / \mathrm{CZ}$, amounts of carbon deposited with respect to SSA are slightly lower than those obtained with bare supports. Portion of the surface might be covered by Ag NPs, hence diminishing the number of acidic sites available for propene adsorption. Therefore, propene seems to preferentially adsorb over the supports acidic sites than over Ag NPs.

\subsubsection{Catalytic performances for carbon oxidation in supertigth contact at iso-amount of carbon}

As the amount of deposited carbon greatly differed from one catalyst to another for a propene cracking period of $30 \mathrm{~min}$, we adjusted the time and the cracking temperature to obtain similar amounts over every samples (at around $40 \mu$ moles of $\mathrm{C}$ ). Experiments parameters and obtained carbon amounts are reported in Table $7 . \mathrm{CZ}$ and $1 \mathrm{Ag} / \mathrm{CZ}$ affinity toward propene lead to a large amount of carbon being deposited in a short time, hence it proved to be difficult to deposit the desired quantity. 
Besides, CZ specific surface properties lead to various byproducts, as parallels reactions producing large amounts of methane and CO. The latter being produced by partial oxidation of propene through the lattice oxygen stored in $\mathrm{CZ}$ due to the high reducibility of $\mathrm{CZ}$ at $600{ }^{\circ} \mathrm{C}$. For these reason, results over $\mathrm{CZ}$ and $1 \mathrm{Ag} / \mathrm{CZ}$ are not shown.

By adjusting the cracking time and temperature, we obtained deposited amount of carbon ranging from 29 to $43 \mu \mathrm{mol}$ for zirconiabased supports and calcined catalysts. Experimental conditions are given in Table 6. $\mathrm{SiO}_{2}$ and $1 \mathrm{Ag} / \mathrm{SiO}_{2}$ displayed lower amounts of 1.5 and $13 \mu \mathrm{mol}$, respectively due to the absence of acidic sites over $\mathrm{SiO}_{2}$. Carbon to silver ratio indicates that the deposited carbon is located on both $\mathrm{Ag}$ NPs and support in the case of $1 \mathrm{Ag} / \mathrm{YSZ}, 1 \mathrm{Ag} / \mathrm{YSZb}$ and $1 \mathrm{Ag} / \mathrm{ZrO}{ }_{2}$. On the opposite, on $1 \mathrm{Ag} / \mathrm{SiO}_{2}$, carbon deposition mainly occurs on $\mathrm{Ag}$ NPs. This is in good agreement with TEM micrographs displayed in Fig. 7. TEM observation was performed over calcined silver-supported samples after propene cracking (following parameters in Table 7). Over zirconia-based silver-supported catalysts, a thin carbon layer of 1-5 nm can be observed at the oxide surface and over Ag NPs. As expected from $1 \mathrm{Ag} / \mathrm{SiO}_{2}$, carbon could only be detected over Ag NPs but not on the support. In comparison with our results, carbon layer thickness obtained by Aneggi et al. through high-energy milling was about $1 \mathrm{~nm}$ with presence of soot clumps resulting from a too large amount of soot compared to the available catalyst surface [38].

$\mathrm{CO}_{2}$ production observed during TPO of these samples after propene cracking are displayed in Fig. 8. Interestingly, carbon oxidation over $1 \mathrm{Ag} / \mathrm{SiO}_{2}$ starts at temperature as low as $150^{\circ} \mathrm{C}$, with a maximum emission of $\mathrm{CO}_{2}$ at $180^{\circ} \mathrm{C}$ (Fig. 8d). Without Ag NPs, $\mathrm{SiO}_{2}$ exhibits a poor activity for carbon oxidation with a negligible production of $\mathrm{CO}_{2}$ starting at $280^{\circ} \mathrm{C}$. These results demonstrate that Ag NPs are very effective for carbon oxidation from $150{ }^{\circ} \mathrm{C}$. However, considering low Ag loadings as in this study, the $\mathrm{Ag} /$ soot interface is statistically very low. For instance, the deposition of a few amount of carbon on Ag NPs was obtained only after two hours in propene at $600^{\circ} \mathrm{C}$. The temperature window of the activity, i.e. $150-250^{\circ} \mathrm{C}$, matches with that of the reduction of $\mathrm{AgO}_{\mathrm{x}}$ species observed during TPR (Fig. 5), suggesting that metallic $\mathrm{Ag}$ NPs are more active than $\mathrm{AgO}_{\mathrm{x}}$ for carbon oxidation.

Over the three other silver-supported catalysts, carbon ignition is triggered at $200^{\circ} \mathrm{C}$. In the absence of silver, carbon ignition occurs at the same temperature over YSZ and YSZb; demonstrating that in supertight contact, carbon oxidation predominantly occurs on the oxide surface, $\mathrm{Ag}$ NPs playing a negligible role in the soot ignition. Such effect can be explained by the wide interface existing between carbon and YSZ, leading to numerous tpb carbon/YSZ/gas which allows fast replenishment of oxygen species into the lattice. On the other hand, the carbon oxidation ignition is enhanced by $\mathrm{Ag}$ NPs on $1 \mathrm{Ag} / \mathrm{ZrO}{ }_{2}$ (Fig. 8c) as the ignition temperature is shifted by $40^{\circ} \mathrm{C}$. This suggests that the intrinsic activity of $\mathrm{ZrO}_{2}$ for soot combustion is lower than that of YSZ and YSZb and confirms that Ag NPs provide active oxygen species from the gas phase as $\mathrm{ZrO}_{2}$ is neither reducible nor ionically conductive.

On $1 \mathrm{Ag} / \mathrm{YSZ}$ and $1 \mathrm{Ag} / \mathrm{YSZb}$, results show that the soot oxidation ignition is driven by the oxide support. However, the presence of Ag NPs accelerates the run-away of the reaction as the maximum of the $\mathrm{CO}_{2}$ emissions are shifted toward lower temperatures. $\mathrm{CO}_{2}$ maximum emission temperatures $\left(\mathrm{T}_{\max }\right)$ is reached at $355^{\circ} \mathrm{C}$ over both $\mathrm{YSZ}$ and $\mathrm{YSZb}$. In presence of silver, $\mathrm{T}_{\max }$ values are lowered to $325^{\circ} \mathrm{C}$ and $300^{\circ} \mathrm{C}$ on $1 \mathrm{Ag} / \mathrm{YSZ}$ and $1 \mathrm{Ag} / \mathrm{YSZb}$, respectively. Similar behavior is observed in the case of $\mathrm{ZrO}_{2}$, with $\mathrm{T}_{\max }$ values of $370{ }^{\circ} \mathrm{C}$ and $340{ }^{\circ} \mathrm{C}$ in absence and presence of silver, respectively. From these $\mathrm{T}_{\max }$ values, one can conclude that the most efficient couple in supertight contact Ag NPs/ oxide is $1 \mathrm{Ag} / \mathrm{YSZb}$.

\subsection{Catalytic performances for soot oxidation of calcined catalysts in loose and tight contact modes}

Silver supported catalysts performances toward soot oxidation were measured by running TPO under different conditions: loose and tight contact modes. Only weak amounts of CO (up to $5 \%$ in total) were detected during TPO which can be attributed to silver high activity for $\mathrm{CO}$ oxidation [43]. Contact mode effect on soot oxidation performances is displayed in Fig. 9. We have considered two parameters : $\mathrm{T}_{10}$ and $\mathrm{T}_{50}$, correspond to temperatures at which 10 and $50 \%$ of the soot are oxidized, respectively. $\mathrm{T}_{10}$ values in both contact modes range from 380 to $505{ }^{\circ} \mathrm{C}$ indicating silver-supported catalysts can be considered for DPF regeneration in term of activity. As previously reported in the literature, both $\mathrm{T}_{10}$ and $\mathrm{T}_{50}$ values are higher in loose contact mode [17,37], as soot oxidation occurs at the soot-catalyst interface, poorer contact conditions lead to lower performances. TPO experiments show the following performances order in both contact modes: $1 \mathrm{Ag} / \mathrm{YSZb}>1 \mathrm{Ag} / \mathrm{ZrO}_{2}>$ $1 \mathrm{Ag} / \mathrm{YSZ}>1 \mathrm{Ag} / \mathrm{CZ}>1 \mathrm{Ag} / \mathrm{SiO}_{2}$.

Highest performances are obtained for $1 \mathrm{Ag} / \mathrm{YSZb}$ with a $\mathrm{T}_{10}$ values of $380^{\circ} \mathrm{C}$ in tight contact, followed by $1 \mathrm{Ag} / \mathrm{ZrO}_{2}$ with $410{ }^{\circ} \mathrm{C}$ (Fig. 9). The catalyst $\mathrm{Ag} / \mathrm{CZ}$ displays lower activity in both tight and loose contact modes although CZ is reported for its high activity toward soot oxidation in the literature $[13,38]$. As expected, the sample $1 \mathrm{Ag} / \mathrm{SiO}{ }_{2}$ is the less effective catalyst with $\mathrm{T}_{10}$ values of 450 and $505^{\circ} \mathrm{C}$ in tight and loose contact modes, respectively.

Lower $\mathrm{T}_{50}$ values in the range $360-400{ }^{\circ} \mathrm{C}$ are reported in the literature for $1 \mathrm{Ag} / \mathrm{ZrO}_{2}$ and $1 \mathrm{Ag} / \mathrm{CeO}_{2}$ catalysts during TPO experiments $[22,31]$. However, TPO conditions differed from this study as soot to catalyst ratio used were $1 / 20$ and $1 / 100$ against $1 / 4$ in this study. In addition, oxygen partial pressures were 10 or $20 \%$ instead of $5 \%$ in our study. Lower soot to catalyst ratio and higher oxygen partial pressure promote soot oxidation runaway as the number of soot/catalyst contact points are higher and the oxygen is more readily available, leading to lower $\mathrm{T}_{50}$ values.

The variations of $\mathrm{T}_{10}$ values as a function of the surface amount of silver, measured by XPS (Table 4) balanced by the overall silver loading (Table 1) are displayed in Fig. 10. This latter shows a linear dependence of $\mathrm{T}_{10}$ values with the accessible fraction of Ag NPs on the surface. Therefore, the soot ignition in both loose and tight contact modes is correlated with the fraction of Ag NPs present over the catalyst surface. Amount of surface metallic Ag NPs are related to different parameters, such as the support porosity. High pore size, as over $1 \mathrm{Ag} / \mathrm{CZ}$ and $1 \mathrm{Ag}$ / $\mathrm{SiO}_{2}$ (Table 2), limits the presence of Ag NPs on the surface as they are mainly located inside pores being inaccessible to soot particles generally of the order of $100 \mathrm{~nm}$ size. The slope of the linear dependence is higher in loose contact mode than in tight one which indicates that the silver impact is more pronounced when the interface between soot and catalyst is limited. Propene cracking experiments proved that soot ignition occurs over YSZ oxide rather than through the Ag NPs in "supertight" contact. In the case of a more limited interface as obtained in loose contact mode, the soot oxidation is mainly activated by Ag NPs, as demonstrated in [11]. An intermediate situation occurs in tight contact mode, where both the support oxide and Ag NPs most probably participate in the soot ignition. Zirconia-based catalysts display the highest fraction of silver at their surface, while $1 \mathrm{Ag} / \mathrm{CZ}$ surface concentration is intermediate and that of $1 \mathrm{Ag} / \mathrm{SiO}_{2}$ is the lowest one in good agreement with soot activity measured by TPO (Fig. 9).

Fig. 10 also displays that, in spite of a similar surface concentration of $\mathrm{Ag}$ NPs, $1 \mathrm{Ag} / \mathrm{YSZb}$ presents a lower $\mathrm{T}_{10}$ value in tight contact than $1 \mathrm{Ag} / \mathrm{YSZ}$, i.e. $380^{\circ} \mathrm{C}$ instead of $420^{\circ} \mathrm{C}$. TPR indicates that $1 \mathrm{Ag} / \mathrm{YSZb}$ contains the highest amount of metallic silver ( $\mathrm{Ag}$ ) as the amount of consumed $\mathrm{H}_{2}$ is the lowest (Table 4). As metallic silver was reported to be the most active silver specie for soot oxidation [17,18,20,22], this could explain the $1 \mathrm{Ag} / \mathrm{YSZb}$ superior activity among zirconia-based catalyst in good agreement with a higher oxygen exchange rate in the temperature domain of the soot ignition (Table 5 and Fig. 6).

\subsection{Catalytic performances for soot combustion of aged catalysts in loose and tight contact modes}

Hydrothermal ageing impact on catalysts catalytic activity was 


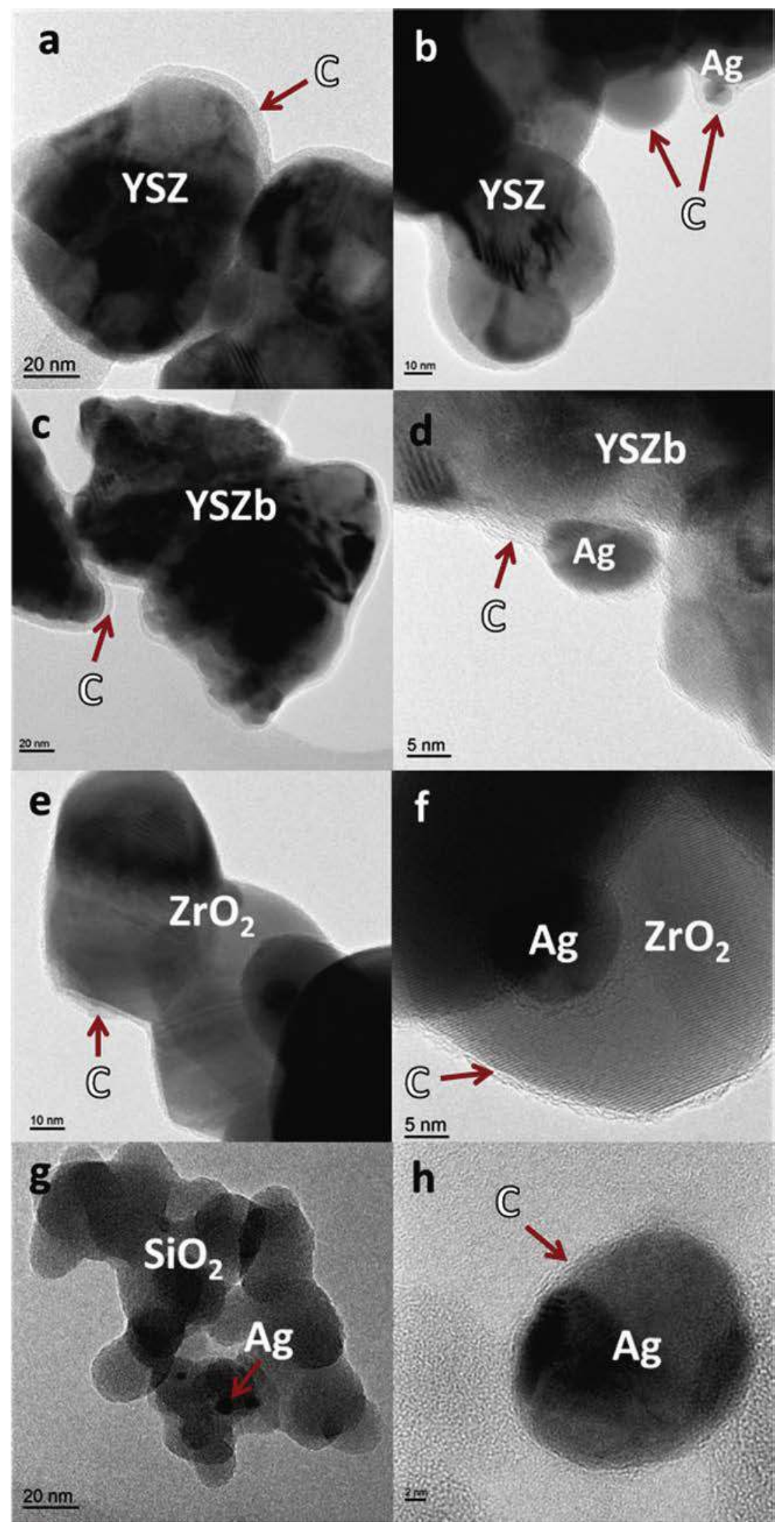

Fig. 7. TEM micrographs of bare supports and silver supported catalysts after propene cracking (conditions described in Table 6): 1Ag-YSZ (a, b); 1Ag-YSZb (c, d); $1 \mathrm{Ag}-\mathrm{ZrO}_{2}(\mathrm{e}, \mathrm{f}) ; 1 \mathrm{Ag}-\mathrm{SiO}_{2}(\mathrm{~g}, \mathrm{~h})$. 

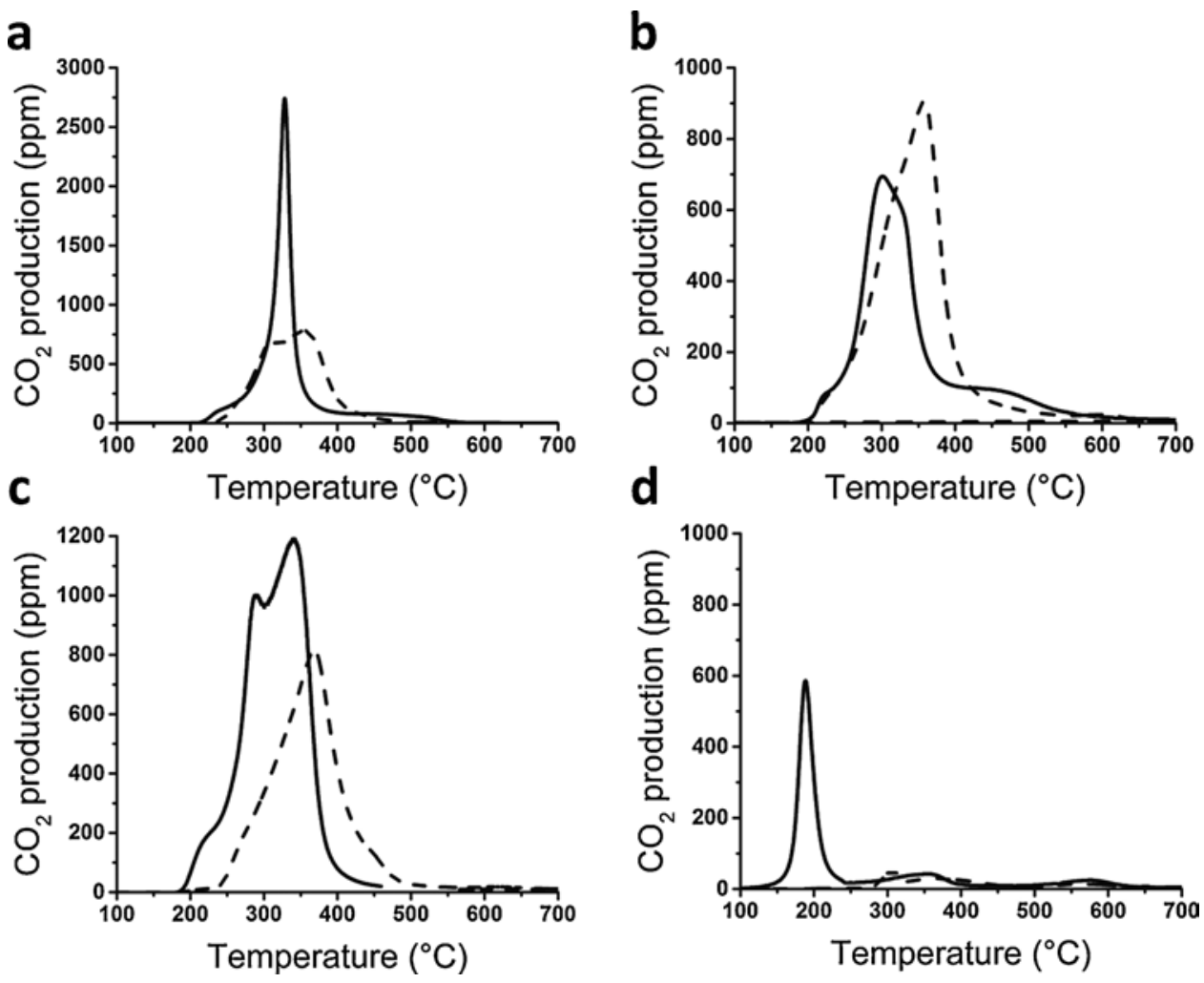

Fig. 8. Production of $\mathrm{CO}_{2}$ with respect to temperature during TPO under $5 \% \mathrm{O}_{2} / \mathrm{He}$ following propene cracking (protocol described in Table 6). Bare supports: dashed curves, silver-supported catalysts: full line. (a) $\mathrm{YSZ}$ et $\mathrm{Ag} / \mathrm{YSZ}$, (b) $\mathrm{YSZb}$ et $\mathrm{Ag} / \mathrm{YSZb}$, (c) $\mathrm{ZrO}_{2}$ et Ag/ZrO,$(d) \mathrm{Ag} / \mathrm{SiO}_{2}$ and $\mathrm{SiO}_{2}$.

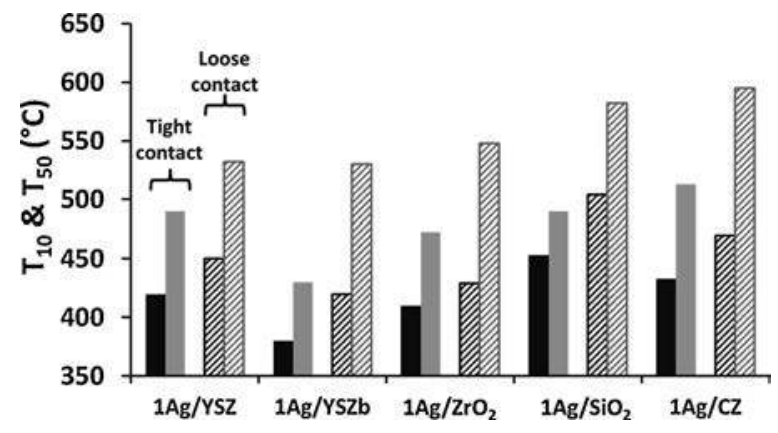

Fig. 9. $\mathrm{T}_{10}$ (black) and $\mathrm{T}_{50}$ (grey) obtained during $\mathrm{TPO}$ under $5 \% \mathrm{O}_{2} / \mathrm{He}$ in tight (full bars) and loose contact (striped bars) modes on calcined catalysts.
Table 5

Amounts of consumed ${ }^{18} \mathrm{O}_{2}$ at $400{ }^{\circ} \mathrm{C}$ and percentage of exchanged ${ }^{16} \mathrm{O}_{2}$ during TPIE experiments.

\begin{tabular}{clll}
\hline Catalysts & $\begin{array}{l}{ }^{18} \mathrm{O}_{2} \text { Exchange rate } \\
\text { at/s/g catalyst at } \\
400{ }^{\circ} \mathrm{C}\left(\mathrm{x} \mathrm{10}^{16}\right)\end{array}$ & $\begin{array}{l}{ }^{16} \mathrm{O}_{2} \text { exchanged } \\
\text { during TPIE }\end{array}$ & $\begin{array}{l}\text { Oxygen exchange } \\
\text { starting temperature }\left({ }^{\circ} \mathrm{C}\right)\end{array}$ \\
\hline $1 \mathrm{Ag} / \mathrm{YSZ}$ & 6.6 & 9.8 & 320 \\
$1 \mathrm{Ag} /$ & 12 & 15.2 & 320 \\
$\mathrm{YSZb}$ & & & \\
$1 \mathrm{Ag} /$ & 14 & 9.7 & 310 \\
$\mathrm{ZrO}$ & & - & 450 \\
$1 \mathrm{Ag} /$ & - & & \\
$\mathrm{SiO} \mathrm{O}_{2}$ & & 28.6 & 330 \\
$1 \mathrm{Ag} / \mathrm{CZ}$ & 11 & & \\
\hline
\end{tabular}

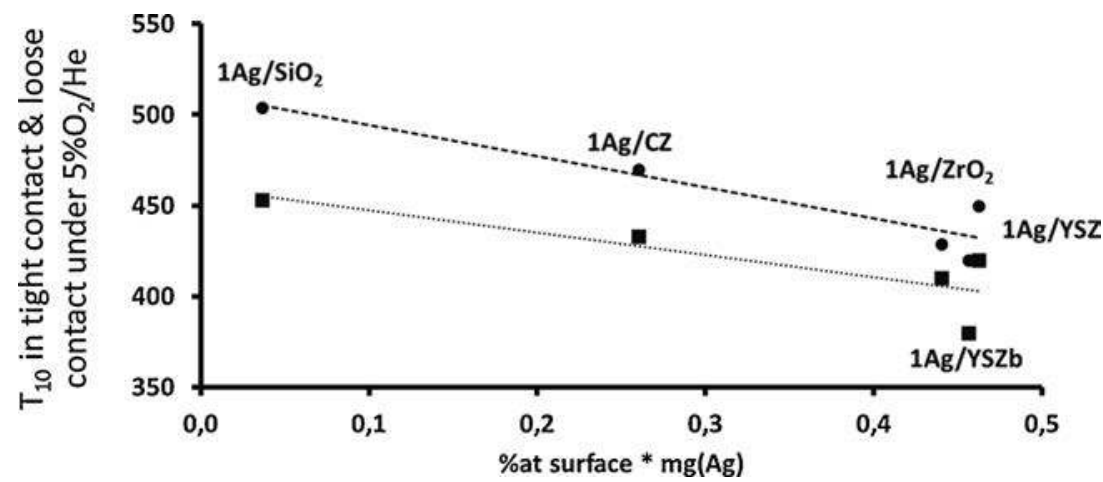

Fig. 10. Values of T10 obtained during TPO experiments in tight (square) and loose (circle) contact under $5 \% \mathrm{O}_{2} / \mathrm{He}$ with respect to the proportion of surface silver multiplied by the amount of silver in the sample. 
Table 6

Amounts of deposited carbon estimated by TPO after $30 \mathrm{~min}$ of propene cracking at $600{ }^{\circ} \mathrm{C}$.

\begin{tabular}{llll}
\hline Catalysts & $\begin{array}{l}\text { Deposited carbon } \\
(\mu \text { moles })\end{array}$ & $\begin{array}{l}\text { Deposited carbon with } \\
\text { respect to SSA }\left(\mu \text { moles } / \mathrm{m}^{2}\right)\end{array}$ & $\begin{array}{l}\text { Carbon to silver } \\
\text { molar ratio }\end{array}$ \\
\hline $\mathrm{YSZ}$ & 3 & 1.3 & $/$ \\
$\mathrm{YSZb}$ & 4 & 2.6 & $/$ \\
$\mathrm{ZrO}_{2}$ & 105 & 35.0 & $/$ \\
$\mathrm{CZ}$ & 400 & 27.8 & $/$ \\
$\mathrm{SiO}_{2}$ & 2 & 0.01 & 1.7 \\
$1 \mathrm{Ag}-\mathrm{YSZ}$ & 36 & 14.9 & 1.3 \\
$1 \mathrm{Ag}-$ & 29 & 24.3 & \\
$\mathrm{YSZb}$ & & & 3.8 \\
$1 \mathrm{Ag}-$ & 79 & 33.0 & \\
$\quad \mathrm{ZrO}$ & & & 19.8 \\
$1 \mathrm{Ag}-\mathrm{CZ}$ & 367 & 25.5 & 0.3 \\
$1 \mathrm{Ag}-\mathrm{SiO}_{2}$ & 8 & 0.2 & \\
\hline
\end{tabular}

Table 7

Parameters of the propene cracking: temperatures, duration and amounts of deposited carbon estimated by TPO for adjusted cracking experiments.

\begin{tabular}{lllll}
\hline Catalysts & $\begin{array}{l}\text { Cracking } \\
\text { temperature }\left({ }^{\circ} \mathrm{C}\right)\end{array}$ & $\begin{array}{l}\text { Cracking time } \\
(\mathrm{min})\end{array}$ & $\begin{array}{l}\text { Deposited carbon } \\
\text { amount }(\mu \mathrm{mol})\end{array}$ & $\begin{array}{l}\mathrm{C} / \mathrm{Ag} \\
\text { ratio }\end{array}$ \\
\hline $\mathrm{YSZ}$ & 650 & 11 & 32 & $/$ \\
$\mathrm{YSZb}$ & 650 & 11 & 36 & $/$ \\
$\mathrm{ZrO}_{2}$ & 580 & 10 & 33 & $/$ \\
$\mathrm{SiO}_{2}$ & 580 & 30 & 1.5 & $/$ \\
$1 \mathrm{Ag}-\mathrm{YSZ}$ & 580 & 30 & 36 & 1.7 \\
$1 \mathrm{Ag}-$ & 580 & 30 & 29 & 1.3 \\
$\mathrm{YSZb}$ & & 10 & 43 & 2.0 \\
$\begin{array}{c}1 \mathrm{Ag}- \\
\mathrm{ZrO}\end{array}$ & 580 & & & \\
$1 \mathrm{Ag}_{2}-\mathrm{SiO}_{2}$ & 580 & 120 & 13 & 0.4 \\
\hline
\end{tabular}

assessed by performing TPO under $5 \% \mathrm{O}_{2} / \mathrm{He}$ in both contact conditions. $\mathrm{T}_{10}$ and $\mathrm{T}_{50}$ values obtained for both contact modes prior to and after ageing are reported in Tables 8 and $9.1 \mathrm{Ag} / \mathrm{SiO}_{2}$ and to a less extent $1 \mathrm{Ag} /$ YSZ and $1 \mathrm{Ag} / \mathrm{ZrO}_{2}$ exhibit a remarkable hydrothermal stability as performances in tight contact mode are fairly similar after ageing (Table 8). Therefore, in spite of the observed Ag NPs loss and sintering, the $\mathrm{Ag}$ surface concentration remains sufficient to ignite soot combustion. $1 \mathrm{Ag} /$ $\mathrm{SiO}_{2}$ stability can be explained by silver being mainly present within the pores before and after ageing without any significant Ag loss, hence displaying limited activity in both cases. On the opposite, the activity of $1 \mathrm{Ag} /$ YSZb significantly drops after ageing with a strong increase of $\mathrm{T}_{10}$ and $\mathrm{T}_{50}$ values of $60^{\circ} \mathrm{C}$ and $80^{\circ} \mathrm{C}$, respectively. This could be due to the yttrium segregation on $1 \mathrm{Ag} / \mathrm{YSZb}$ which was found to be strongly promoted by the ageing (Table 3), reaching the same level than that on $1 \mathrm{Ag} / \mathrm{YSZ}$. The segregation of yttrium on the surface most probably amplifies the surface carbonation by increasing the surface basicity. Surface carbonates could limit the contact points with soot and/or decorate the Ag NPs.

Catalytic performances drop are also noticeable on $1 \mathrm{Ag} / \mathrm{CZ}$ with $\mathrm{T}_{10}$ values increasing by $25^{\circ} \mathrm{C}$ and $40^{\circ} \mathrm{C}$ in tight and loose contact mode, respectively. These performances after ageing are the poorest ones in loose contact, probably due to the concomitant loss of $\mathrm{Ag}(40 \% \mathrm{wt})$ and sintering of the CZ support (Tables 1 and 2). Similar behavior was described by Aneggi et al. over silver-supported ceria and zirconia aged at $850{ }^{\circ} \mathrm{C}$ in presence of $10 \% \mathrm{H}_{2} \mathrm{O}$ [31]. In the case of $\mathrm{Ag} / \mathrm{CeO}_{2}, \mathrm{~T}_{50}$ were shifted by 40 and $50{ }^{\circ} \mathrm{C}$ in tight and loose contact, respectively. Activity loss was associated with the lower thermal stability of the support, as observed in this study.

The catalytic performances in tight contact mode are very similar for all aged catalysts except those of $1 \mathrm{Ag} / \mathrm{CZ}$ (Table 8). In loose contact mode (Table 9), where the role of Ag NPs becomes predominant, $1 \mathrm{Ag}$ / YSZb remains the best catalyst $\left(\mathrm{T}_{10}=460^{\circ} \mathrm{C}\right.$ upon ageing), even if the activity difference with $1 \mathrm{Ag} / \mathrm{YSZ}$ became small.
Table 8

Values of $\mathrm{T}_{10}$ obtained during TPO under $5 \% \mathrm{O}_{2} / \mathrm{He}$ in tight contact mode for calcined and aged catalysts.

\begin{tabular}{|c|c|c|c|c|c|c|}
\hline \multirow[b]{2}{*}{ Catalysts } & \multicolumn{6}{|c|}{ Tight contact mode } \\
\hline & $\begin{array}{l}\mathrm{T}_{10} \\
\text { calcined } \\
\left({ }^{\circ} \mathrm{C}\right)\end{array}$ & $\begin{array}{l}\mathrm{T}_{10} \\
\text { aged } \\
\left({ }^{\circ} \mathrm{C}\right)\end{array}$ & $\begin{array}{l}\Delta \mathrm{T}_{10} \\
\left({ }^{\circ} \mathrm{C}\right)\end{array}$ & $\begin{array}{l}\mathrm{T}_{50} \\
\text { calcined } \\
\left({ }^{\circ} \mathrm{C}\right)\end{array}$ & $\begin{array}{l}\mathrm{T}_{50} \\
\text { aged } \\
\left({ }^{\circ} \mathrm{C}\right)\end{array}$ & $\begin{array}{l}\Delta \mathrm{T}_{50} \\
\left({ }^{\circ} \mathrm{C}\right)\end{array}$ \\
\hline 1Ag/YSZ & 420 & 440 & 20 & 490 & 500 & 10 \\
\hline $\begin{array}{l}\text { 1Ag/ } \\
\text { YSZb }\end{array}$ & 380 & 440 & 60 & 430 & 510 & 80 \\
\hline $\begin{array}{l}1 \mathrm{Ag} / \\
\mathrm{ZrO}_{2}\end{array}$ & 410 & 435 & 25 & 470 & 500 & 30 \\
\hline $\begin{array}{l}1 \mathrm{Ag} / \\
\mathrm{SiO}_{2}\end{array}$ & 450 & 450 & 0 & 490 & 510 & 20 \\
\hline $1 \mathrm{Ag} / \mathrm{CZ}$ & 435 & 475 & 40 & 510 & 540 & 30 \\
\hline
\end{tabular}

Table 9

Values of $\mathrm{T}_{10}$ obtained during TPO under $5 \% \mathrm{O}_{2} / \mathrm{He}$ in loose contact mode for calcined and aged catalysts.

\begin{tabular}{|c|c|c|c|c|c|c|}
\hline \multirow[b]{2}{*}{ Catalysts } & \multicolumn{6}{|c|}{ Loose contact mode } \\
\hline & $\begin{array}{l}\mathrm{T}_{10} \\
\text { calcined } \\
\left({ }^{\circ} \mathrm{C}\right)\end{array}$ & $\begin{array}{l}\mathrm{T}_{10} \\
\text { aged } \\
\left({ }^{\circ} \mathrm{C}\right)\end{array}$ & $\begin{array}{l}\Delta \mathrm{T}_{10} \\
\left({ }^{\circ} \mathrm{C}\right)\end{array}$ & $\begin{array}{l}\mathrm{T}_{50} \\
\text { calcined } \\
\left({ }^{\circ} \mathrm{C}\right)\end{array}$ & $\begin{array}{l}\mathrm{T}_{50} \\
\text { aged } \\
\left({ }^{\circ} \mathrm{C}\right)\end{array}$ & $\begin{array}{l}\Delta \mathrm{T}_{50} \\
\left({ }^{\circ} \mathrm{C}\right)\end{array}$ \\
\hline $1 \mathrm{Ag} / \mathrm{YSZ}$ & 450 & 470 & 20 & 530 & 550 & 20 \\
\hline $\begin{array}{l}\text { 1Ag/ } \\
\text { YSZb }\end{array}$ & 420 & 460 & 40 & 530 & 540 & 10 \\
\hline $\begin{array}{l}1 \mathrm{Ag} / \\
\mathrm{ZrO}_{2}\end{array}$ & 430 & 485 & 55 & 550 & 560 & 10 \\
\hline $\begin{array}{l}1 \mathrm{Ag} / \\
\mathrm{SiO}_{2}\end{array}$ & 505 & 505 & 0 & 580 & 580 & 0 \\
\hline $1 \mathrm{Ag} / \mathrm{CZ}$ & 470 & 520 & 50 & 595 & 600 & 5 \\
\hline
\end{tabular}

\section{Conclusion}

The impact of the soot/catalyst contact quality on the performances for soot combustion of Ag NPs dispersed on two different YttriaStabilised Zirconia supports (YSZ and YSZb), $\mathrm{ZrO}_{2}, \mathrm{SiO}_{2}$ and ceriazirconia was carried out using a low Ag loading (around $1 \mathrm{wt} \%$ ). Three contact modes were investigated: loose and tight using model soot and supertight achieved from in-situ deposition of nanometric layers of carbon via propene cracking. Using this latter protocol, we found that the ignition of the carbon oxidation occurs on YSZ and YSZb surface, Ag NPs only promoting the run-away of the reaction at higher temperatures. On the opposite, the Ag NPs role is significant on $\mathrm{ZrO}_{2}$ whereas, on $\mathrm{SiO}_{2}$, carbon is only oxidized by Ag NPs. The soot ignition in both loose and tight contact modes is clearly linked with the Ag surface concentration which was found to be high on zirconia-based catalysts, especially on YSZb, and significantly lower on ceria-zirconia. This confirms that the rate-determining step of the soot oxidation ignition on $\mathrm{Ag} / \mathrm{YSZ}$ is not the YSZ active oxygen spillover but the incorporation of gaseous oxygen into YSZ. Furthermore, catalysts based on $\mathrm{SiO}_{2}, \mathrm{ZrO}_{2}$ and YSZ exhibit a remarkable hydrothermal stability as performances in tight contact mode are fairly similar after ageing.

\section{Supporting information}

Isotopic oxygen exchange on bare zirconia supports.

\section{References}

[1] E. Aneggi, C. de Leitenburg, A. Trovarelli, Catal. Today 181 (2012) 108-115. 
[2] E. Aneggi, N.J. Divins, C. de Leitenburg, J. Llorca, A. Trovarelli, J. Catal. 312 (2014) 191-194.

[3] S. Liu, X. Wu, D. Weng, R. Ran, J. Rare Earths 33 (2015) 567-590.

[4] D. Fino, N. Russo, G. Saracco, V. Speechia, J. Catal. 217 (2003) 367-375.

[5] N. Russo, D. Fino, G. Saracco, V. Specchia, J. Catal. 229 (2005) 459-469.

[6] W.Y. Hernandez, M.N. Tsampas, C. Zhao, A. Boreave, F. Bosselet, P. Vernoux, Catal. Today 258 (2015) 525-534.

[7] F.E. López-Suárez, A. Bueno-López, M.J. Illán-Gómez, J. Trawczynski, Appl. Catal. Gen. 485 (2014) 214-221.

[8] A. Serve, T. Epicier, M. Aouine, F.J. Cadete Santos Aires, E. Obeid, M. Tsampas, K. Pajot, P. Vernoux, Appl. Catal. Gen. 504 (2015) 74-80.

[9] E. Obeid, L. Lizarraga, M.N. Tsampas, A. Cordier, A. Boréave, M.C. Steil, G. Blanchard, K. Pajot, P. Vernoux, J. Catal. 309 (2014) 87-96.

[10] E. Obeid, M.N. Tsampas, S. Jonet, A. Boréave, L. Burel, M.C. Steil, G. Blanchard, K. Pajot, P. Vernoux, Solid State Ion. 262 (2014) 253-256.

[11] A. Serve, A. Boreave, B. Cartoixa, K. Pajot, P. Vernoux, Appl. Catal. B Environ. 242 (2019) 140-149.

[12] A. Trovarelli, Catal. Rev. 38 (1996) 439-520.

[13] E. Aneggi, D. Wiater, C. de Leitenburg, J. Llorca, A. Trovarelli, ACS Catal. 4 (2014) $172-181$.

[14] J.P.A. Neeft, O.P. van Pruissen, M. Makkee, J.A. Moulijn, Appl. Catal. B Environ. 12 (1997) 21-31.

[15] B.A.A.L. van Setten, M. Makkee, J.A. Moulijn, Catal. Rev. 43 (2001) 489-564.

[16] J. Sun, D. Ma, H. Zhang, X. Liu, X. Han, X. Bao, G. Weinberg, N. Pfänder, D. Su, J. Am. Chem. Soc. 128 (2006) 15756-15764.

[17] E. Aneggi, C. de Leitenburg, G. Dolcetti, A. Trovarelli, Catal. Today 136 (2008) $3-10$.

[18] G. Corro, U. Pal, E. Ayala, E. Vidal, Catal. Today 212 (2013) 63-69.

[19] L. Kundakovic, M. Flytzani-Stephanopoulos, Appl. Catal. Gen. 183 (1999) 35-51.

[20] K. Yamazaki, T. Kayama, F. Dong, H. Shinjoh, J. Catal. 282 (2011) 289-298.

[21] M. Haneda, A. Towata, Catal. Today 242 (2015) 351-356.

[22] T. Nanba, S. Masukawa, A. Abe, J. Uchisawa, A. Obuchi, Catal. Sci. Technol. 2 (2012) 1961-1966.
[23] K. Shimizu, H. Kawachi, S. Komai, K. Yoshida, Y. Sasaki, A. Satsuma, Catal. Today 175 (2011) 93-99.

[24] J.A. Moulijn, F. Kapteijn, Carbon 33 (1995) 1155-1165.

[25] J. Zhu, J. Vanommen, A. Knoester, L. Lefferts, J. Catal. 230 (2005) 291-300.

[26] J. Texter, J.J. Hastreiter, J.L. Hall, J. Phys. Chem. 87 (1983) 4690-4693.

[27] K.A. Bethke, H.H. Kung, J. Catal. 172 (1997) 93-102.

[28] F. Giordano, A. Trovarelli, C. de Leitenburg, M. Giona, J. Catal. 193 (2000) 273-282.

[29] Z. Qu, W. Huang, M. Cheng, X. Bao, J. Phys. Chem. B 109 (2005) 15842-15848.

[30] T. Nanba, S. Masukawa, A. Abe, J. Uchisawa, A. Obuchi, Appl. Catal. B Environ. 123-124 (2012) 351-356.

[31] E. Aneggi, J. Llorca, C. de Leitenburg, G. Dolcetti, A. Trovarelli, Appl. Catal. B Environ. 91 (2009) 489-498.

[32] M. Skaf, S. Aouad, S. Hany, R. Cousin, E. Abi-Aad, A. Aboukaïs, J. Catal. 320 (2014) 137-146.

[33] J. Zhu, J.G. van Ommen, H.J.M. Bouwmeester, L. Lefferts, J. Catal. 233 (2005) 434-441.

[34] D. Martin, D. Duprez, J. Phys. Chem. 100 (1996) 9429-9438.

[35] R. Baker, J. Guindet, M. Kleitz, J. Electrochem. Soc. 144 (1997) 2427-2432.

[36] F. Liang, W. Zhou, Z. Zhu, ChemElectroChem 1 (2014) 1627-1631.

[37] B.A.A.L. van Setten, J.M. Schouten, M. Makkee, J.A. Moulijn, Appl. Catal. B Environ. 28 (2000) 253-257.

[38] E. Aneggi, V. Rico-Perez, C. de Leitenburg, S. Maschio, L. Soler, J. Llorca, A. Trovarelli, Angew. Chem. Int. Ed. 54 (2015) 14040-14043.

[39] T. Viinikainen, H. Rönkkönen, H. Bradshaw, H. Stephenson, S. Airaksinen, M. Reinikainen, P. Simell, O. Krause, Appl. Catal. Gen. 362 (2009) 169-177.

[40] B.K. Vu, E.W. Shin, J.-M. Ha, S.K. Kim, D.J. Suh, W.-I. Kim, H.-L. Koh, Y.G. Choi, S.B. Lee, Appl. Catal. Gen. 443-444 (2012) 59-66.

[41] K.T. Jung, A.T. Bell, J. Mol. Catal. Chem. 163 (2000) 27-42.

[42] J.A. Anderson, C. Fergusson, I. Rodríguez-Ramos, A. Guerrero-Ruiz, J. Catal. 192 (2000) 344-354.

[43] Z. Qu, M. Cheng, W. Huang, X. Bao, J. Catal. 229 (2005) 446-458. 